\title{
Yönetsel Alanda Değişimler ve Devrim Hareketlerine Karşı Gerici Tepkiler "Serbest Cumhuriyet Fırkası - Menemen Olayı"
}

\author{
Dr. Necdet AYSAL *
}

\begin{abstract}
$\ddot{O z e t}$
Mustafa Kemal Paşa'nın önderliğinde başlatılan toplumsal dönüşüm hareketi, Türk toplumunu çağ dışı bırakan uygulamaları sona erdirmiş ve çağdaş topluma giden yolun önünü açmıştır. Bununla birlikte laik düzen ve dünya görüşü doğrultusunda birbiri ardınca gerçekleşen devrimler, dinsel kurallara bağlı çevrelerin tepkisine neden olmuştur. İşte bu ortamda Mustafa Kemal Paşa'nın isteği doğrultusunda çok partili demokratik hayata geçiş için başlatılan girişimler de (Terakkiperver Cumhuriyet Fırkası ve Şeyh Sait İsyanı), olumsuz sonuçlanmıştır.

Bu çalışmada çok partili demokratik hayata geçiş için atılan ikinci adım ele alınmıştır. Özellikle 1929 başlayan ve 1930'lu yıllarda etkisini daha çok hissettiren Dünya Ekonomik Bunalımı, özellikle sanayileşmiş şehirleri vurmuş ve Türkiye bu bunalımdan fazlasıyla etkilenmiştir. Bu arada ekonomik sıkıntılar sonucunda baş gösteren huzursuzluğun çözümünün yeniden çok partili siyasal hayata geçmekle bulunabileceği düşünülmüşs ve Serbest Cumhuriyet Fırkası kurulmuştur. Fakat bu girişimde uzun süreli olmamış, Fırka'nın yaşanan sıkıntı ve siyasi gelişmelerle kısa bir süre sonra kapandı̆̆ görülmüştür. Nitekim Serbest Cumhuriyet Fırkası'nın kapanmasının ardından laik hukuk düzenine ve Cumhuriyete karşı çıkarllan gerici bir ayaklanma "Menemen Olayı”, henüz çok partili demokratik hayata geçişin erken olduğunu ispatlayacaktır.
\end{abstract}

Anahtar Kelimeler: Serbest Cumhuriyet Fırkast, Menemen Olayl, Terakkiperver Cumhuriyet Firkası, Seyh Sait Isyanı, Mustafa Kemal Paşa, Ismet (İönü) Paşa, Fethi (Okyar) Bey, Asteğmen Mustafa Fehmi Kubilay Bey, Giritli Mehmet.

\footnotetext{
${ }^{*}$ Ankara Üniversitesi Türk İnkılap Tarihi Enstitüsü, Öğretim Görevlisi
} 


\section{Changes in the Administrative Field and Unprogressive Reactions Against Revolution Movements "Liberal Republican Party - Menemen Incident" \\ Abstract}

The social transformation movement initiated under the leadership of Mustafa Kemal Pasha had ended implementations causing Turkish society outdated and gave way to road to contemporary society. Besides, the revolutions eventuated one after another in line with the secular order and world vision caused reactions of societies connected to religious rules. Within this environment, upon the request of Mustafa Kemal Pasha, also the attempts (Progressive Republican Party and Seyh Sait Rebellion) which were initiated for transition to multi party democratic life resulted negative.

In this work, the second step taken for the transition to multi party democratic life is discussed. Particularly, the World Economic Crisis which started in 1929 and showed its affects in 1930's, hit the industrialized cities and Turkey was extremely affected from this crisis. In the mean time, it has been thought that transition to multi party political life once again can be a solution for the anxiousness resulted from the economic constraints and Liberal Republican Party had been established. However, this attempt will not be long term and with troubles and political developments experienced, it will be seen that the party will be closed within a short time. As a matter of fact, after the closing of the Liberal Republican Party, "Menemen Incident" an unprogressive rebellion which was risen against secular law order and Republic will prove that it is early for transition to multi party democratic life.

Key Words: Liberal Republican Party, Menemen Incident, Progressive Republican Party, Seyh Sait Rebellion, Mustafa Kemal Pasha, İsmet (Inönü) Pasha, Mr. Fethi (Okyar), Lieutenant Mr. Mustafa Fehmi Kubilay, Giritli Mehmet.

\section{GíRIŞ}

Türk Kurtuluş Savaşı'nı zaferle sona erdirmeyi başaran yeni Türk Devleti, bu mücadelenin ikinci aşaması olan çağdaş bir devlet ve toplum yaratma sürecini başlatmak için, iç politikaya önem vermiştir ${ }^{1}$. Bu süreçte, iç politikada köklü değişiklikler gerçekleştirilecek ve bu değişikliklerin hızlı bir şekilde hayata geçirilmesi sağlanacaktır.

Savaşın sona ermesiyle birlikte, ulusal egemenliğin önünde bir engel teşkil eden Saltanat makamı, yeni devletin iç politikasını bir hayli meşgul

${ }^{1}$ Şerafettin Turan, Türk Devrim Tarihi, Ulusal Direnişten Türkiye Cumhuriyeti'ne, 1. B., 2. Kitap, Ankara, Bilgi Yayınevi, 1992, s. 292-298. 
etmiştir ${ }^{2}$. Lozan Barış Konferansı öncesi bu konunun çözümü, barış görüşmelerinin önünü açmış ve Yeni Türk Devleti'nin tek başına Lozan'da temsil edilmesini sağlamıştır' ${ }^{3}$. Bu arada Lozan Barışı'nın imzalanmasından sonra ortaya çıan hükümet bunalımı, devlet başkentinin resmen ilan edilmemesi gibi sorunlar, Meclis Hükümeti sisteminin artık işlemediğini göstermiş ve bu durum Cumhuriyetin ilanını zorunlu hale getirmiştir. İç politikada yaşanan bu sıkıntılar, önce Ankara'nın başkent ilan edilmesi ${ }^{4}$ ve arkasından Cumhuriyetin ilan edilmesi ile ortadan kaldırılmıştır ${ }^{5}$. Böylece ulusal egemenlik ilkesi biraz daha güçlendiriliyor ve halkın yönetime katılmasının yolu açılıyordu.

Türkiye Cumhuriyeti Devleti, demokratik ve laik gelişme yolunda en önemli adımı Halifeliğin kaldırılması ile atmıștır ${ }^{6}$. Toplumsal birlik ve beraberliğin sağlanması yolunda atılan bu adımla, Batılı devletlerin iç işlerine müdahale etmelerinin yolunu kapatmıştır. Bununla birlikte laik düzen ve dünya görüşü doğrultusunda birbiri ardınca gerçekleştirilen devrimler, dinsel kurallara bağlı çevrelerin tepkilerine yol açmış ve eski düzeni savunan ve ilk firsatta ona dönülmesini arzulayan çevreleri yeniden harekete geçirmiştir. İşte bu ortamda kuruluşu gerçekleşen Terakkiperver Cumhuriyet Fırkas1, yeni Cumhuriyetin siyasi hayatında önemli bir dönüm noktasını teşkil etmiş ve rejimin gereği olarak çok partili siyasal hayata geçilmiştir ${ }^{7}$. Fakat bu dönem fazla uzun süreli olmamış, yapılan devrimlerle çıkarları zedelenen ve eski düzeni yeniden geri getirmek isteyen çevreler, doğuda önemli bir isyanın çıkmasına ön ayak olmuşlardır.

Şeyh Sait İsyanı, yıllarca geri kalmışlığın acısını çıkarmak, insanca yaşama özlemi ile çağdaş uygarlık düzeyine ulaşmak için yapılan hızlı devrim aşamalarına karşı en büyük ve önemli bir tepkidir. Bu isyan, ülkede hükümet değişikliklerine ve pek çok önemli kanunun yürürlüğe sokulmasına neden olmuştur. Nitekim Hükümetin almış olduğu sert önlemlerle bastırılan bu isyan, yeni kuruluşu gerçekleşen ve henüz örgütlenmesini tamamlayamayan Terakkiperver Cumhuriyet Firkası'nın kapatılmasına

\footnotetext{
${ }^{2}$ Sina Akşin, Ana Çizgileriyle Türkiye'nin Yakın Tarihi 1789-1980, 4. B., Ankara, İmaj Yayıncilik, 2001, s. 162.

${ }^{3}$ Mahmut Goloğlu, Türkiye Cumhuriyeti, Ankara, Başnur Matbaası, 1971, s. 275.

4 İsmet İnönü, Hatıralar, 2. Kitap, Ankara, Yenigün Haber Ajansı Basın ve Yayıncılık A.Ş., 1999, s. 166-168.

Kazım Özalp, Teoman Özalp, Atatürk'ten Anılar, 4. B., Ankara, Türkiye İș Bankası Kültür Yayınları, 1998, s. 26-27.

${ }_{7}^{6}$ TBMM Zabit Cerideleri, II. Devre, C. 7, 3 Mart 1924 (1340). s. 28-29.

7 Tarık Zafer Tunaya, Türkiye'de Siyasi Partiler, 2. B., İstanbul, Hürriyet Vakfi Yay., 1986, s. 606; Ergün Aybars, İstiklal Mahkemeleri 1920-1927, İzmir, Dokuz Eylül Üniversitesi Yayınları, 1988, s. 256-261.
} 
neden olacaktır ${ }^{8}$. Böylece Türkiye'de çok partili siyasal yaşama geçiş denemesi başarısızlıkla sona ermiş ve bu olay Türk toplumunun henüz demokrasi için hazır olmadığını açıkça göstermiştir.

İç politikada yaşanan bu siyasi gelişmeler, yapılan devrimlerin hızını kesmemiştir. Artık siyasal yollarla mücadele imkânlarının kalmadığını ve kişisel çıkarlarını nasıl gerçekleştirebileceklerini düşünen devrim karşıtları, Mustafa Kemal Paşa'yı yok ettikleri takdirde, Cumhuriyet rejimini yıkabileceklerini düşünmeye başlamışlardı. Fakat bu kimseler, böylesine büyük cinayeti gerçekleştirmek için kendilerinde gerekli cesareti bulamamışlardır'.

\section{SERBEST CUMHURIYET FIRKASI}

Türkiye Cumhuriyeti Devleti'nin kurulmasından sonra çok partili demokratik hayata geçiş için atılan ikinci adım "Serbest Cumhuriyet Fırkası"nın kuruluşu ile gerçekleşmiştir. Cumhurbaşkanı Mustafa Kemal Paşa'nın teşviki ve telkini ile kurulan bu fırka, Türk siyasal hayatında bir takım tartışmaların yeniden alevlenmesine neden olacaktır. ${ }^{10}$.

Bilindiği üzere 1930 yılı, Türkiye'de bir takım zorlukların ve sıkıntıların yaşandığı bir dönem olmuştur. Özellikle birbiri ardınca çok hızlı gerçekleşen devrimler ve bu konularda alınan çeşitli önlemler, muhalif gurubun tepkisini çekmiş ve hükümete karşı direnişi artırmıştır. Bunun yanı sıra Ekim 1929'da patlak veren ve kısa süre içinde tüm dünyayı etkisi altına alan ekonomik bunalım da, Türkiye'yi fazlasıyla etkilemiştir ${ }^{11}$. O günlerde Mustafa Kemal Paşa'nın yurt içindeki gezilerinden birine katılan Ahmet Hamdi (Başar) Bey şu değerlendirmelerde bulunmaktadır ${ }^{12}$ :

"Vergi işi... Nereye gitsek vergilerin ă̆ırlı̆̆ından, alınma tarzının kötülüğünden, bu yolda yapılan zulümlerden şikayet edildiği görülüyor. Ekseriye vergisini ödeyemediğinden tarlası, evi-barkı satılmış olanların

${ }^{8}$ Ergün Aybars, Ístiklal Mahkemeleri 1920-1927, İzmir, Dokuz Eylül Üniversitesi Yayınları, 1988, s. 256-261.

9 Temuçin F. Ertan ve Diğerleri, Atatürk ilkeleri ve Inkılap Tarihi, 1. B., Ankara, Ankara Üniversitesi Uzaktan Eğitim Yayınları, 2008, s. 196.

${ }_{10}$ Tarık Zafer Tunaya, Türkiye'de Siyasi Partiler, 2. B., İstanbul, Hürriyet Vakfi Yay., 1986, s. 613-614.

${ }_{11}$ Uluslararası piyasada düşen fiyatlar, Türk ihraç ürünlerinin durumunu da etkilemiş, yeni gümrük tarifelerinin yürürlüğe girmesi iç piyasa ve halkın yaşamını oldukça zorlaştırmıştır. $\mathrm{Bu}$ arada Hükümetin sanayileşme siyaseti, alkollü içkilerin, siggara, şeker, tuz ve deniz nakliyatının devlet tekeline alınması halkın hoşnutsuzluğunu daha da arttıracaktır. Bkz., Erdoğan Teziş, Atatürk Döneminin Ekonomik ve Toplumsal Sorunları, İstanbul, İktisadi ve Ticari İlimler Akademisi Mezunlar Derneği Yay., 1977, s. 70-72.

${ }_{12}$ Tevfik Çavdar, Türkiye'nin Demokrasi Tarihi (1839-1950), 2. B., Ankara, İmge Kitabevi, 1999, s. 296. 


\begin{abstract}
facialarl, onlarl dinleyenlerin vicdanlarında acı etkiler yaptığ halde, konmuş kanunlar ve usullere göre de bir şey yapılamıyor. Geçtiğimiz her yerde bir şikayet konusu da Ziraat Bankası'na aitti. Ziraat Bankaları köylüye borç para vermiyor, çiftçi eli bögrü̈nde banka kapılarında dolaşıyor. Halbuki aynı banka şehirde tüccara kredi açmaktadır. Tüccar bankadan para alıyor ve köylüye ikraz ediyor..."
\end{abstract}

$\mathrm{Bu}$ gezi surasında Mustafa Kemal Paşa, ülkenin içinde bulunduğu ekonomik bunalımı Genel Sekreteri Hasan Rıza (Soyak) Bey’e şu sözlerle ifade etmiştir ${ }^{13}$ : “... Bunalıyorum çocuk, büyük bir istırap içinde bunallyorum. Görüyorsun ya her gittiğimiz yerde dert, şikâyet dinliyoruz. Her taraf derin bir yokluk, maddi-manevi perişanlık içerisinde...". Kısaca, memleket her alanda büyük bir huzursuzluk içinde kalmış; eleştiriyi kaldırmanın, basını susturmanın, Meclis muhalefetine imkân vermemenin, tek başına iktidarda olmanın bunalımı yok etmeye, huzuru getirmeye yararı olmamıştır. Tersine denetimsiz parlamentonun yarattı̆̆ günden güne büyümüş ve ekonomik sıkıntılar her geçen gün $\operatorname{artmiştır~}^{14}$.

Cumhurbaşkanı Mustafa Kemal, toplumda, basında ve TBMM'de giderek artan hoşnutsuzlukların bir yerde patlak vermesinden, merkez denetiminin yitirilmesinden endişe etmektedir ${ }^{15}$. Özellikle yaşanan ekonomik ve siyasi bunalımların toplumsal bir patlamaya dönüşmesini istemeyen Mustafa Kemal Paşa, tüm bu sorunların çözümü için bir muhalefet partisinin kurulmasını uygun görmüştür. Nitekim Cumhuriyetin ve onun ayrılmaz bir parçası haline gelen devrimlerin de ayrıca korunması gerekmektedir.

1930 yılına gelindiğinde siyasal ortamdaki bu tür gelişmeler, Cumhuriyet Halk Fırkası'nın yumuşak bir politika izleyerek muhalefete olanak vermesi, "Serbest Cumhuriyet Firkası"nın kurulmasında en önemli etken olacaktı1 ${ }^{16}$. 17 Kasım 1924'te kurulan Terakkiperver Cumhuriyet Fırkası'ndan olumlu sonuç alınamayışının kendine özgü nedenleri vardı. Fırka, siyasal rejim henüz yeterince bilinmeden, algılanmadan doğmuştu. Kurucular erken davranmışlar ve firkaya egemen olamamışlardı. Aradan geçen 5 yıl içerisinde o deneyimden her kesimin bazı dersler almış olması

\footnotetext{
${ }^{13}$ Hasan Riza Soyak, Atatürk'ten Hatıralar, C. I-II, İstanbul, Yapı ve Kredi Bankası Yayınları, 1973, s. 44.

${ }^{14}$ Mahmut Goloğlu, Devrimler ve Tepkileri (1924-1930), Ankara, Başnur Matbaası, 1972, s. 276.

5 Şerafettin Turan, Türk Devrim Tarihi, Yeni Türkiye'nin Oluşumu 1923-1938, 3. Kitap, Ankara, Bilgi Yayınevi, 1995, s. 292.

Mete Tunçay, Türkiye Cumhuriyeti'nde Tek Parti Yönetiminin Kurulması (19231931), Ankara, Yurt Yayınları, 1981, s. 247.
} 
gerekirdi. Dolayısıyla Cumhuriyetin en belirgin ve en güvenilir kişilerin öncülüğünde kurulacak ikinci bir partinin kimi sıkıntıları gidereceği ve CHF'nın olduğu kadar, hükümetin de daha etkin olarak denetleneceği düşünülüyordu ${ }^{17}$.

Mustafa Kemal, bu düşünce ve varsayımla yeni bir partinin kurulması için doğrudan doğruya kendisi harekete geçmiştir. CHF karşısında yer alacak olan kuruluşun başkanlığı için de, çok eski arkadaşı olan ve 1lımlılığı ile tanınan eski Başbakan Fethi (Okyar) Bey'i seçmiştir ${ }^{18}$. O, muhalefet görevini üzerine alacak ama kendisine sadık kalacak bir partinin kurulmasını temenni ediyordu. Nitekim muhalif bir partinin kurulmasından maksat, birikmiş hoşnutsuzlukların giderilmesini sağlamak ve hükümetin hem kusurlarını düzeltmeye hem de ekonomik duruma yeni çareler aramaya sevk edecek bir kontrol sistemi yaratmaktan ibaretti ${ }^{19}$.

Serbest Cumhuriyet Fırkası'nın kuruluş aşaması, Paris Büyükelçisi Fethi (Okyar) Bey'in 1930'da yaz tatilini geçirmek üzere Türkiye'ye gelmesiyle başlamıştır. İstanbul Büyükdere'de ki Necmettin Molla Köşkü'nde misafir edilen Fethi Bey, o sırada Yalova Termal Tesisleri'nde dinlenen Mustafa Kemal'e, ülkenin içerisinde bulunduğu ekonomik durumla ilgili olarak ayrıntılı bir rapor sunmuştur ${ }^{20}$. Bu görüşmeler sırasında İsmet Paşa Hükümeti ile ilgili görüş ve eleştirilerini de Gazi'ye iletme firsatı bulan Fethi Bey' $\mathrm{e}^{21}$, Mustafa Kemal tarafından yeni bir partinin kurulmasının teklif edildiği görülecektir. Gazi'ye göre, ülkenin içinde bulunduğu bu sıkıntılardan ancak muhalif bir partinin kurulmasıyla aş1labilecek ve memleketin sorunları Meclis’te muhalefet kanadının görüşleriyle tartışılacak, çözümler daha kolay olacaktı ${ }^{22}$. Mustafa Kemal kurulacak olan partinin başına Fethi (Okyar) Bey'in geçmesini istemiş ve "Bir parti kur, başına geç ve düşüncelerini Meclis'te müdafaa et. Bu suretle particilikten beklenen faydayı da temin etmiş olursun" demiştir ${ }^{23}$. Fakat Fethi Bey, bu teklif üzerine

${ }_{17}^{17}$ Turan, s. 292.

${ }^{19}$ Kemal H. Karpat, Türk Demokrasi Tarihi, 2. B., İstanbul, Afa Yayınlar1, 1996, s. 61; Hâkimiyet-i Milliye, "Yeni Frrka", 10 Ağustos 1930, Pazar, No. 3260, s. 1, 3.

${ }^{20}$ Cavdar, Türkiye'nin Demokrasi Tarihi 1839-1950, s. 297; Fethi Okyar, Üc Devirde Bir Adam, Yay. Haz., Cemal Kutay, İstanbul, Adam-Tercüman Yayınlar1, 1980, s. 386-390; İlhan Tekeli-Selim İlkin, 1929 Dünya Buhranında Türkiye’nin İktisadi Politika Arayışları, Ankara, Orta Doğu Teknik Üniversitesi, 1977, s. 154-156.

${ }^{21}$ Fethi Bey, ülkenin içinde bulunduğu ekonomik durumu özetleyerek, borçların ertelenmesi yoluna gidilmemesini, böyle bir durumun itibarımızı zedeleyeceğini ve Türkiye'yi zor durumda bırakacağını söylemiş, ayrıca ülkenin bu durumdan kurtulabilmesi için Fransız Hükümeti'nin yardıma hazır olduğunu Mustafa Kemal'e anlatmıştır. Bkz., Okyar, s. 386-387.

${ }_{22}^{2}$ Goloğlu, Devrimler ve Tepkileri, s. 277.

${ }^{23}$ Hamza Eroğlu, Türk İnklap Tarihi, I. B., Ankara, Savaş Yayınları, 1990, s. 242. 
şaşıracak ve Gazi'ye İsmet Paşa ile karşı karşıya gelmek istemediğini söyleyecektir. Gerekçesi ise, Paris Büyükelçiliği görevi sırasında Duyun-u Umumiye taksitlerinin ödenmesi konusunda Başbakan İsmet (İnönü) Paşa ile anlaşmazlığa düşmesidir ${ }^{24}$. Bu arada İsmet Paşa da Yalova'ya gelmiş ve Mustafa Kemal tarafindan kendisine bilgi verilerek, görüşlerinin ne olduğu sorulmuştur. İsmet Paşa ise, yeni bir partinin kurulmasının kendilerini de memnun edeceğini, muhalif bir partiden gelecek olan eleştirilerin hükümete yararlı olacağını bildirmiştir ${ }^{25}$. Nitekim bu görüşme ve tartışmalar olumlu sonuçlanmış ve 7 Ağustos 1930'da Fethi Bey'in "Serbest Cumhuriyet Fırkası" adında bir parti kurması kararlaştırılmıştır. Fethi Bey'in liberal anlayışını da yansıtan firkanın adı, Atatürk tarafından bulunmuştur. Ancak Fethi Bey'in bu partinin kuruluşunda bazı koşullar öne sürdüğü de bilinmektedir. $\mathrm{Bu}$ koşulların en önemlisi, Cumhurbaşkanının partiler arasında tarafsız kalması ve bu partinin Mustafa Kemal Paşa'nın isteği ve müsaadesi ile kurulduğuna dair yazılı bir belgenin istenmesi konusudur ${ }^{26}$. Fethi Bey, bu isteklerinde kendince haklıdır. Çünkü Mustafa Kemal Paşa'ya karşı çıkmaya kalkmanın gerçekçi olmadığını bilen SCF liderinin korkusu, yalnız hükümete değil devlete de muhalif olma durumuna düşerek belki de hryanet-i vataniye ile suçlanmaktır ${ }^{27}$.

$\mathrm{Bu}$ endişelerin ortadan kaldırılmasından sonra, yeni parti liderinin Meclis'te bulunabilmesi için ilk açılacak milletvekilliğine getirilmesi kararlaştırılmıştır $^{28}$. Gazi Mustafa Kemal, Serbest Fırka ile ilgili olarak kamuoyunun bilgisini almak istemiş ve partinin resmen kurulmasından önce

${ }^{24}$ Duyun-u Umumiye ve Borçlar Kanunu, İmparatorluktan Cumhuriyet Türkiyesi’ne kalan önemli konuların başında gelmektedir. Lozan Görüşmeleri'nden sonra bu konu Paris Büyükelçisi Fethi Bey aracılığı ile devam ettirilmiştir İsmet Paşa Hükümeti borçların kağıt para ile ödenmesini isterken, alacaklı ülkeler altın olarak ödenmesinde israr ediyorlardı. 1928 yılında alacaklı ülkelerle bir antlaşma imzalanmış ve Türkiye borçlarının bir bölümünün silinmesine karşılık borçlarını altın olarak ödemeyi kabul etmiştir. Antlaşmayı Fethi Bey imzalamıs ve bu anlaşma o dönemde takdirle karşılanmıștır. Fakat anlaşmanın uygulanma safhasında işler değişmiş, taksitlerin ödenmesi 1929 bunalım dönemine rastlamış̦tır. İnönü Hükümeti antlaşmanın uygulanamayacağını bildirerek ödemelerin altın olarak değil de kâğıt para ile yapılacağını bildirmiștir. Bu durum antlaşmanın imzalayıcısı Fethi Bey'i çok zor durumda bırakmıș ve İsmet Paşa ile aralarının açılmasına neden olmuștur. Bkz., Asım Us, Gördüklerim Duyduklarım, Duygularım, Meşrutiyet ve Cumhuriyet Devirlerine Ait Hatıralar ve Tetkikler, İstanbul, Vakit Matbaası, 1964, s. 133-137.

25 "...bugün bize düssen vazife, bizi tenkit eden bir firkanın zuhuruna karşı endişe ve çatık çehre göstermeksizin onu, güler yüzle karşılamaktır..." Ayrıntıll bilgi için bkz. Hâkimiyet-i Milliye, "İsmet Paşa Yeni Fırka Hakkında Ne Düşünüyorlar?”, 11 Ağustos 1930, Pazartesi, No. 3261, s. 1

${ }_{26}^{26}$ Hâkimiyet-i Milliye, "Yeni Furka", 10 Ağustos 1930, Pazar, No. 3260, s. 3.

${ }^{27}$ Mete Tunçay, Türkiye Cumhuriyeti'nde Tek-Parti Yönetiminin Kurulması (19231931) 3. B., İstanbul, Cem Yayınevi, 1992, s. 253.

2810 gün sonra Gümüşhane Milletvekili Cemal Hüsnü Bey, Bern Elçiliği'ne atanmak üzere milletvekilliğinden ayrilmış ve boşalan Gümüşhane milletvekilliğine Fethi (Okyar) Bey getirilmiştir. Bkz. Goloğlu, s. 277. 
buna ilişkin bir haberin basında yayınlanmasını uygun bulmuștu. Bu amaçla Vakit gazetesinden Asım (Us) Bey Yalova'ya çağrılmıştır. Mustafa Kemal Paşa, yeni yapılan bir otelin açılışında düzenlenen baloda, İnönü ve Okyar'1 da yanına alarak bir masaya oturmuş ve Asım (Us) Bey'in de masaya çağrılmasından sonra şu konuşmayı gerçekleştirmiştiir ${ }^{29}$ :

\footnotetext{
"Ben şimdi bir babayım. Siz ikiniz de benim evladımsınız. İkiniz arasında benim nazarımda hiçbir fark yoktur. Benim istediğim sadece memleket işlerinin Büyük Millet Meclisi'nde açıç̧a münakaşa edilmesidir. Büyük Millet Meclisi'nde Türk milletinin gözü önünde açıkça konuşulamayacak hiçbir iş yoktur..."
}

Mustafa Kemal'in bu sözleri, ülkenin çok partili siyasal hayata geçerken beklentisinin ne olduğunu açıkça gözler önüne sermektedir. O, İkinci Meşrutiyet döneminin ve Terakkiperver Cumhuriyet Fırkası deneyiminin doğurduğu iç mücadelelerin yinelenmemesini ve aynı zamanda parlamenter sistemin gereği olarak tartışmaların TBMM'de yoğunlaştırılmasını istemektedir. Ayrıca kendisinin de partiler karşısında yansız kalacağını vurgulamaktadır ${ }^{30}$.

9 Ağustos 1930'da Vakit gazetesinde bu anlayış doğrultusunda çıkan ilk haberin arkasından, Mustafa Kemal ve Fethi Bey arasında Serbest Firka'nın uyacağı kurallara ilişkin karşılıklı yazışmalar da yapılmıştır. Fethi (Okyar) Bey'in 9 Ağustos 1930 tarihinde Mustafa Kemal Paşa'ya göndermiş olduğu mektupta, iç huzursuzlukta ilk göze çarpan sıkıntının ekonomik ve mali durumdaki bunalım olduğu ve bu bunalımın genel sebepler dışında beş yıldan beri izlenen ekonomik ve mali politikalardan ileri geldiği vurgulanmaktadır. Hükümetin gereksiz harcamalarla halktan dayanamayacağı kadar vergi aldığını, ihracatın korunmadığını, iç ve dış siyasette noksanlıklar bulunduğunu ve bunun Meclis'te tek partinin bulunmasından kaynaklandığını belirten Fethi Bey, tek parti mensuplarının kendi hükümetlerini eleştirmekten çekindiklerini, dolayısıyla kendi durumu hakkındaki endişelerini şu sözlerle açığa vurmaktadır ${ }^{31}$ :

${ }^{29}$ Asım Us, Gördüklerim, Duyduklarım, Duygularım..., s. 132.

${ }^{30}$ Turan, Türk Devrim Tarihi, 3. Kitap, s. 294.

${ }^{31}$ Mektubun tam metni için bkz. Ahmet Ağaoğlu, Serbest Fırka Hatıraları, 2. B., İstanbul, Baha Matbaası, 1969, s. 7-8; Okyar, Üç Devirde Bir Adam, s. 428-430; Hasan Riza Soyak, Atatürk'ten Hatıralar, C. II, Ankara, Yap1 ve Kredi Bankası Yayınları, 1973, s. 413 414; Hâkimiyet-i Milliye, 11 Ağustos 1930, Pazartesi, No. 3261, s. 2. 
“...Cumhuriyet Halk Fırkası'nın mali, iktisadi, dâhili ve harici siyasetlerinin birçok noktalarına aykırı bulunan ayrı bir firka ile siyasi mücadele sahnesine atılmak arzusundayım. Zat-ı Devletleri Reis-i Cumhur olmaktan mâ̂da şimdiye kadar mensup bulunduğum Cumhuriyet Halk Fırkası'nın da umumi reisi olmaları dolayısıla, iş bu arzumun nazâr-ı devletlerinde ne yolda kabul buyuracă̆ını bilmek lüzumunu hissediyorum."

Fethi Bey'in bu mektubuna Gazi Mustafa Kemal Paşa, 10 Ağustos 1930 günü, tarafsızlığını koruyacağını ve bunun Cumhurbaşkanlığının gereği olduğunu dile getirerek, kurulacak siyasi partinin faaliyetlerinin engellenilmeyeceğini ama laik Cumhuriyet esaslarından da kesinlikle taviz verilmeyeceğini belirten bir mektupla karş1lık vermiştir ${ }^{32}$ :

\footnotetext{
"Azizim Fethi Beyefendi, ...Lâik Cumhuriyet esası dâhilinde Fırkanızın her nevi siyasi faaliyet cereyanlarının bir maniaya ŭgramayacă̆ına emniyet edebilirsiniz..."
}

Mustafa Kemal Paşa, yeni partiye güven vermek için çocukluk arkadaşı Milletvekili Nuri (Conker) Bey ile Tahsin (Uzer) ve hatta kız kardeşi Makbule (Atadan) Hanım'ın bu yeni kuruluşta görev almalarını istemiştir ${ }^{33}$. Gazi'nin emirle, yeni firkaya üye yaptığ bir başka kişi de Ağaoğlu Ahmet Bey'dir. Ağaoğlu Serbest Fırka'ya girişini, Seyr-i Sefain İdaresi tarafindan Yalova Kaplıcaları'nda Termal- Büyük Otel salonunda düzenlenen bir baloda öğrenmiştir ${ }^{34}$.

Mustafa Kemal Paşa'dan yazılı güvence alan Fethi Bey, "Serbest Cumhuriyet Fırkası"nın kuruluşunu içeren dilekçeyi 12 Ağustos 1930 tarihinde Yalova'dan telgrafla İstanbul Valiliği'ne göndermiş ve bu başvuru ile firkanın resmen kuruluşu onaylanmıştır ${ }^{35}$. İlk merkezini İstanbul-

${ }^{32}$ Atatürk'ün Söylev ve Demeçleri, C. II, 5. B., Ankara, Atatürk Araștırma Merkezi Yayınları, 1997, s. 257; A ̈̆aoğlu, s. 9; Atatürk'ün Tamim, Telgraf ve Beyannameleri, C. IV, Ankara, Atatürk Araştırma Merkezi, 1991, s. 544; Hâkimiyet-i Milliye, "Gazi Hazretleri Fethi Bey'e Cevap Verdiler.”, 12 Ağustos 1930, Sali, No. 3262, s. 1.

33 Turan, s. 296-297; Fethi Bey anılarında Gazi'ye Mustafa diye hitap edebilen tek kişinin Nuri Conker olduğunu söylemektedir. Bkz., Çavdar, Türkiye'nin Demokrasi Tarihi, s. 298.

${ }^{34}$ Asım Us, s. 127; Çağlar Kırçak, Meşrutiyetten Günümüze Gericilik, 2. B., Ankara, İmge Kitabevi, 1994, s. 282.

5 Tarık Zafer Tunaya, Türkiye'de Siyasi Partiler (1859-1952), 2. B., İstanbul, Arba Yayınları, 1995, s. 622-623; Karpat, s. 55-63; Osman Akandere, Milli Şef Dönemi, Çok Partili Hayata Geçişte Rol Oynayan İç ve Dış Nedenler, İstanbul, İz Yayıncılık, 1998, s. 23; 
Taksim'de açan Fırkanın Genel Başkanı eski Başbakan, TBMM Başkanı, Paris Büyükelçisi Ali Fethi (Okyar) Bey ve Genel Sekreteri Kütahya Milletvekili Nuri (Conker) Bey'dir. Genel yönetici kadrosunda ise, Ahmet (Ağaoğlu), Tahsin (Uzer), Mehmet Emin (Yurdakul) ${ }^{36}$, Nakiyettin (Yücekök), Semih (Hızıroğlu), Ali Haydar (Yuluğ), Ali Galip (Yenen), Refik İsmail (Kakmac1), İbrahim (Tolon), Rasim (Öztekin), Talat (Sönmez), Süreyya (İlmen) ve Doktor Reşit Galip'ten oluşan 14 milletvekili görev almıştır $^{37}$.

Serbest Fırka'ya üye milletvekillerinin durumları hakkında, Fethi Bey ile Gazi Mustafa Kemal arasında geçen konuşmalarda, Gazi'nin Emin, Rasim ve Naki Beylere sahip çıktığı ve "ötekilere karışmam" şeklinde bir cevap verdiği görülmektedir. Fethi Bey ise, bu duruma şu sözlerle itiraz etmiştir ${ }^{38}$ :

“... Hepsinin mesuliyeti sizin üzerinizdedir. Daha benim malumatım olmadan ve firka resmen kurulmadan Ağaoğlu Ahmet Bey'i firkaya dahil eden sizsiniz. Hocaniz Naki Bey'e, Şair Mehmet Emin Bey'e, Tahsin Bey ve İbrahim Bey'e benim yanımda emir verdiniz. Diğerlerini de yanınızda iken teklif ettiniz. Hepsi, rejime kadar, sizin arzularınızı emir telâkki etmenin ihlâsl içinde kabul ettiler. Ya hepsinden mesulsünüz ya da hiçbirinden değilsiniz...”

Fethi Bey'in bu itirazına Mustafa Kemal Paşa, “...Siz bilmezsiniz... Bunların çoğu zaten İsmet Paşa'ya ve siyasetine aleyhtardır. Ben rast gele teklifte bulunmadım." şeklinde karşıllık vermiştir ${ }^{39}$.

Cumhuriyet Halk Fırkası karşısına Cumhuriyetçi, laik ama liberal bir anlayışla çıkan partinin programı 11 maddeden oluşmaktadır ${ }^{40}$ :

Hâkimiyet-i Milliye, 13 Ağustos 1930, "Serbest Cumhuriyet Firkası Teşekkül Etti.", Çarşamba, No. 3263, s. 1.

Sarki-Karahisar Mebusu Mehmet Emin Bey'in CHP'den ayrlarak Serbest Cumhuriyet Firkası'na geçmesiyle ilgili bkz., B.C.A, Dos. 2. Büro, Fon. 490. 1. 0. 0, Yer. 527. 654. 211.. 3, (28.8.1930).

Hâkimiyet-i Milliye, "Serbest Cumhuriyet Fırkası Teșekkül Etti.", 13 Ağustos 1930, Çarşamba, No. 3263, s. 1.

${ }_{38}^{38}$ Okyar, Uç Devirde Bir Adam, s. 536-537.

${ }^{39}$ A.g.e., s. 537.

${ }^{40}$ Hâkimiyet-i Milliye, "Serbest Cumhuriyet Fırkası Teşekkül Etti.", 13 Ağustos 1930, Çarşamba, No. 3263, s. 1. 
"1- Serbest Cumhuriyet Fırkası, Cumhuriyetçilik, milliyetçilik ve Laiklik esaslarına bağlıdır. Bu esasların millet bünyesinde ebedileşmesi gayesidir. Teşkilat-ı Esasiye Kanunu'ndaki hürriyet ve masuniyet hakları bilaistisna herkes için meri kllacak ve hiç bir arızaya uğramayacaktır. 2 Vergiler millet efradının iktisadi teşebbüs ve faaliyetini sarsmayacak ve halkın takatı hududunu aşmayacak derecede tahdit edilecektir. Vergi tarzında daha salim esaslara istinat edilecek ve tahsilindeki yolsuzluklar kaldirllacaktır..."

16 Ağustos 1930'da Serbest Cumhuriyet Fırkası, Nazlı Han'da ki yeni binasında yurt düzeyinde örgütlenme ve yayılma çalışmalarına hız vermiştir ${ }^{41}$. Ulusal Bağımsızlık Savaşı yıllarında Çerkes Ethem ile birlikte "Seyyare-i Yeni Dünya" adlı komünist eğilimli bir gazete çıkartmış olan Arif Oruç'un sahibi olduğu "Yarın" gazetesi ile Zekeriya Sertel'in yazı işleri müdürlüğünü yaptığ1 "Son Posta" gazetesi, yeni partiyi destekleyip onun yayın organları durumuna gelmiştir ${ }^{42}$.

Yeni Parti, Büyük Millet Meclisi'nde III. Dönemin tatil devresinde kurulduğu için, Meclis'te pek verimli olamamış, fakat kuruluşundan kapanışına kadar Meclis'in ancak 13 oturumuna katılabilen firka, oturumlarda kısmen söz sahibi olmayı başarmıştır. Serbest Cumhuriyet Fırkas1, Cumhuriyet Halk Fırkası ve hükümetini çok ağır suçlamalarla eleştirmiş ve Fethi Bey'in basına verdiği demeçte, “... Demiryolu yapımının tek bir kuşağa gücünü aşan vergiler yüklediğini, tekellerin halka çok ă̆ır geldiğini, paranın değerinin her geçen gün düştüğ̈̈ ve bu yüzden yabancı sermayenin gelmediğini" ileri sürmesi, iki parti arasındaki gerginliğin bir kat daha artmasına neden olmuştur. Ayrıca Fethi Bey'in her konuşmasının arkasından "ilk firsatta, en kisa zamanda" iktidara gelmeyi arzulayan sözleri Atatürk'ü düşündürmüş ve "siz hemen birkaç ay içerisinde iktidara geçmeye uğraşlyorsunuz. Hiç beklemeye tahammül göstermiyorsunuz. Bugün iktidarda olanları düşürüp yerine geçecek olursanız, bu memleketi güven ve huzur içinde tutabilecek misiniz?" sözleriyle Fethi Bey'i hem uyarmış hem de kaygısını dile getirmiştir ${ }^{43}$. Fethi Bey'in bu suçlamalarına Başbakan İsmet

${ }^{41}$ Hâkimiyet-i Milliye, "Serbest Fırka Faaliyete Başladı.”, 17 Ağustos 1930, Pazar, No. 3267, s. 1 .

Hâkimiyet-i Milliye, "Yeni Fırka Reisinin Yeni Beyanatı, Fethi Bey Teșkilatla Meşgul Oluyor,", 15 Ağustos 1930, Cuma, No. 3265, s. 1-4; Goloğlu, s. 282; Turan, s. 298.

${ }^{3}$ Us, Gördüklerim İstanbul,, Duyduklarım, Duygularım, s. 142. 
Paşa da, 30 Ağustos 1930'da Sivas Demiryolunu işletmeye açarken ayrıntılı yanıtlar vermiştir ${ }^{44}$ :

"Bizim politikamızın ana hatlarl, Türk tarihinin seyri bilhassa Istiklal Mücadelesi'nin safhalarl, istıraplarl ve ihtiyaçları göz önünde bulundurulmaksızın anlaşılamaz."

Tartışmalar sürüp giderken Serbest Cumhuriyet Fırkası yöneticileri, basında ve kamuoyunda buldukları desteğe dayanarak ilk seçimde iktidara geleceklerine inanmışlardı. Halkın Fırka'ya karşı gösterdiği büyük ilgi, Fethi Bey ve arkadaşlarının İzmir gezisinde tüm açıklığı ile ortaya çıkmıştır ${ }^{45} .3$ Eylül 1930 'da parti teşkilatını kurmak üzere İzmir'e giden Genel Başkan Fethi Bey ${ }^{46}$, eşi görülmemiş büyük bir halk kalabalığı tarafından karşılanmıştır. Fethi Bey ile İzmir'e giden ve Serbest Parti Yönetim Kurulu üyesi olan Kars Milletvekili Ahmet (Ağaoğlu) Bey, eşine gönderdiği mektupta o günü şöyle anlatmaktadır ${ }^{47}$ :

“...Uzaktan şehir görünmeye başladı. Dürbünlerle baktık. Bütün sahil halkla dolmuştu. Deniz kıyısına en az kırk bin kişi gelmişti. Yaşasın Gazi, yaşasın Fethi Bey, Yaşasın Serbest Firka sesleri her tarafi çınlatıyordu... Gemi istilaya uğrad,, ellerimizi, elbiselerimizi öpüyorlardl. Sıkıştırılmaktan bayılacak hale geldik. Zorla karaya çıkabildik... Gece yarısına kadar otelimizin çevresi insanlarla dolu idi..."

Serbest Cumhuriyet Furkası'na gösterilen bu büyük ilgi, Cumhuriyet Halk Partilileri endişelendirmişti. Nitekim Fethi (Okyar) Bey'in yapacağı konuşmayı engellemek isteyen İzmir Valisi Kazım (Dirik) Bey, Mustafa Kemal Paşa'nın devreye girmesiyle yumuşamış ve sorun çözülmüştür. Bu arada Denizli Milletvekili Haydar Rüștü Bey'in "Anadolu" isimli gazetesinde Serbest Firka aleyhinde yazdığı yazı ise bardağı taşıran son damla olmuştur. Fethi Bey'in konuşturulmasına engel olmanın imkânı

${ }^{44}$ Başbakan İsmet Paşa'nın konuşma metni için bkz. Hâkimiyet-i Milliye, "Sivas İstasyonu Dün Büyük Merasimle Açıldı ve Muhterem Başvekilimiz Atideki Mühim Nutuklarını İrat Ettiler.”, 31 Ağustos 1930, Pazar, No. 3281, s. 1.

${ }^{5}$ Hâkimiyet-i Milliye, "Karşı Fırkanın Reisi İzmir'e Gitti.”, 4 Eylül 1930, Perşembe, No. 3285 , s. 3 .

Hâkimiyet-i Milliye, "SCF Lideri İzmir'e Gitti. Nutkunu Cumartesi Günü Söyleyecek.", 5 Eylül 1930, Cuma, No. 3286, s. 5.

A 
kalmadığını gören Halk Partililer, hiç olmazsa kalabalığın büyük olmaması için tedbirler almaya başlamışlardır.

İzmir'de Fethi Bey'i karşılamaya gelen Serbest Cumhuriyet Fırkası'nın taraftarları İzmir Palas Oteli'nin önünde, Cumhuriyet Halk Fırkası'nın taraftarları ise İkinci Beyler Sokağı ile Bahribaba Parkı'nda toplanarak gösteriler yapmaya ve çeşitli sloganlar atmaya başlamışlardır. Bu arada Cumhuriyet Halk Firkası mutemedi Salih Bey'in Halk Fırkası merkez binası balkonundan Serbest Fırka taraftarlarına hitaben "Yaşasın Halk Fırkası" şeklindeki sloganına, karşıt grubun "Yaşasın Fethi Bey, Kahrolsun mutemetler" sloganıyla karşılık vermesi ortamı gerginleştirmiştir. Bu sırada bina içerisinde bulunan Sabri Bey'in de halka "Namussuzlar" diye bağırması çatışmanın başlamasına neden olmuştur. Çıkan olaylarda öfkeli kalabalık binanın camlarını taşlayıp kırmış ve binanın levhasını dahi sökmüştür. $\mathrm{Bu}$ arada binada bulunan Foça mutemedinin de yaralandığı görülmektedir ${ }^{48}$.

Cumhuriyet Halk Fırkası merkez binasının taşlanıp levhasının sökülmesinden sonra iyice heyecanlanan halk, Denizli Mebusu Haydar Rüştü Bey'in sahibi olduğu Anadolu Gazetesi matbaasına doğru ilerlemiştir. Olaylar sırasında kalabalık grup tarafından atılan taşlar, bir komiser ve jandarma erinin yaralanmasına sebep olmuştur. Olayın daha da büyümesi üzerine güvenlik güçleri öfkeli kalabalığı dağıtmak için havaya ateş açmış ve göstericiler ise bu ateşe taş atarak karşl1ık vermiştir. Bu yaşanan arbede sırasında 14 yaşlarında Necati Kemal isminde mektepli bir genç vurularak ölmüş, 7 kişi ise çeşitli yerlerinden yaralanmıștır ${ }^{49}$. Bu esnada öfkeli kalabalığın dağılmadığı ve Fethi Bey'in kaldığ İzmir Palas Oteli'ne doğru yürüyüşe geçtiği görülmektedir. Ahmet (Ăgaoğlu) Bey, hatıralarında yaşanan bu olay hakkında şu bilgileri vermektedir ${ }^{50}$ :

\footnotetext{
"Kalabalığın ortasından ihtiyar bir adamcă̆ız kucağında taşıdığı bir çocuğu birden bire Fethi Bey'in ayaklarının dibine atarak, 'Isste size bir kurban, başkalarını da veririz. Yalnız sen bizi kurtar' dedi ve ağlayarak kendisi de Fethi Bey'in ellerine sarıld. Manzara müthiş tüyler ürpertici idi. Kanlara boyanmış körpe mektepli çocuk, Fethi Bey'in ayakları altında son nefesini veriyordu... Fethi Bey'in gözleri yaşarmış, bazıları hüngür hüngür ağllyorlardl."
}

${ }^{48}$ Hâkimiyet-i Milliye, “İzmir'de Şayan-1 Teessüf ve Teessür Hadiseler”, 6 Eylül 1930, Cumartesi, No. 3287 , s. 1 .

4 Hâkimiyet-i Milliye, “Fethi Bey İzmir'e Gittiği Gün Neler Oldu?”, 6 Eylül 1930, Cumartesi, No. 3287, s. 2; Çetin Yetkin, Serbest Cumhuriyet Fırkası Olayı, İstanbul, Karacan Yayınları, 1982, s. 243. 63-64.

${ }^{50}$ Ahmet Ağaoğlu, Serbest Fırka Hatıraları, 2. B., İstanbul, Baha Matbaası, 1969, s. 
Serbest Cumhuriyet Furkas1 lideri Fethi Bey'in telkinleri öfkeli kalabalığ1 yatıştırmaya yetmemiş ve "kana kan isteriz" diye bağırarak harekete geçen topluluğa, güvenlik güçleri ikinci kez müdahale etmek zorunda kalmış ve bu arada açılan ateş sonucunda 12 yaşında bir çocuk daha vurularak ölmüştür. Toplam iki ölü ve on beș kişinin ağır yaralandığı bu olaylar güçcükle bastırılabilmiştir ${ }^{51}$.

Olayların yatıştırılmasından sonra 7 Eylül günü İzmir Alsancak Stadında yapılan mitinge büyük bir kalabalık topluluğu katılmıştır. Büyük güvenlik önlemleri altında konuşmasını yapmak üzere saat on altıda kürsüye çıkan Serbest Cumhuriyet Fırkası Başkanı Fethi Bey, kendi parti programlarına dayanarak liberal anlayış doğrultusunda Cumhuriyet Halk Fırkası'nı ağır bir dille eleştirmiştir. Bu sırada göstericilerden bazılarının başlarındaki şapkaları çıkarıp yerlere attıkları da görülmektedir ${ }^{52}$.

Bu konuşma, İnönü Hükümeti’nde derin bir şaşkınlık ve kızgınlık yaratmıştır. Nitekim İzmir olayları, Serbest Fırka'ya karşı CHF liderlerinin özellikle Mustafa Kemal'in kuşkuya düşmesinin başlangıcı sayılabilir ${ }^{53}$. CHF'nin içine sindiremediği nokta ise, Gazi'nin Fırkanın kurucusu ve önderi olduğu halde Serbest Fırka tarafından adeta tarafsız bir lider gibi kabul edilmesidir $^{54}$. Nitekim 9 Eylül 1930 tarihli Cumhuriyet gazetesinde Yunus Nadi (Abalığlu) Bey'in, Gazi'ye hitaben açık bir mektubu yayınlanmış ve bu mektupta İzmir olayları sırasında CHF binalarına ve bazı yöneticilerine yapılan hücumlara değinilerek, Gazi'nin kesin tutumunun bilinmesindeki yarardan söz edilmektedir. Gazi'nin bu mektuba yazmış olduğu cevap ise, aynı gazetenin 10 Eylül tarihli sayısında çıkmış ve bu mektupta özellikle şu noktanın altı çizilmiştir ${ }^{55}$ :

“...Gerçeği bir kere daha ifade ve tasrih edeyim ki ben, CHF'nin umumi reisiyim. CHF, Anadolu'ya ilk ayak bastığım andan itibaren teşekkül edip, benimle çalışan Anadolu ve Rumeli Müdafaa-i Hukuk Cemiyeti'nden

\footnotetext{
${ }^{51}$ Hâkimiyet-i Milliye, 6 Eylül 1930, s. 2; Us, s. 20-25; Goloğlu, s. 284-285.

2 Kürsüde Fethi Bey'in yanında Serbest Fırka'nın umumi kâtibi Nuri Bey, Fırka arkadaşlarından Ağaoğlu Ahmet, Tahsin ve Haydar Bey ile Yeni Asır gazetesinin başyazarı İsmail Hakkı, Behzat Arif Beyler ile Serbest Fırka'nın İzmir il yöneticileri bulunmaktadır. Bkz., Hâkimiyet-i Milliye, "Fethi Bey Nutkunu Söyledi”, 8 Eylül 1930, Pazartesi, No. 3289, s. 3 .

${ }^{53}$ Hâkimiyet-i Milliye, "Fırkalar Karşısında Gazi”, 8 Eylül 1930, Pazartesi, No. 3289, s. 1.

${ }^{54}$ Hâkimiyet-i Milliye, "Reis-i Cumhur Hazretleri ve Yeni Frrka", 9 Eylül 1930, Sal1, No. 3290 , s. 1.

5 Atatürk'ün Tamim, Telgraf ve Beyannameleri, C. IV, s. 545; Hâkimiyet-i Milliye, "Reis-i Cumhur Hazretleri Milleti Tenvir Ediyor", 10 Eylül 1930, Çarşamba, No. 3291, s. 1.
} 
doğmuştur. Bu teşekküle tarihen bağllyım. Bu bă̆ çözmem için hiçbir sebep ve lüzum yoktur ve olamaz."

$\mathrm{Bu}$ mektup ve mektuba verilen cevapta Mustafa Kemal, Serbest Cumhuriyet Fırkası kurulurken tarafsız kalacağına dair verdiği garantiyi ortadan kaldırmış ve Cumhuriyet Halk Fırkası'ndan yana ağırlığını koymuştur. Bu durum ise SCF için zor günlerin habercisi olacak ve Gazi'nin desteğini yitiren firkanın zor durumda kalacağı görülecektir. Her şeyden önce İzmir gezisi ve meydana gelen olaylar, Serbest Fırka için hem olumlu hem de olumsuz sonuçlar doğurmuştur. Bu gezinin olumlu yönü Serbest Cumhuriyet Fırkası'nın büyük bir taraftar toplaması ve güç gösterisinde bulunmasıdır ${ }^{56}$. Olumsuz yönü ise Gazi'nin partiden desteğini çekmesiyle birlikte partiyi irticai güçler ele geçirecek ve tüm bu olaylar partinin sonunu hazırlayacaktır.

İzmir ve Karşıyaka'da Fırka teşkilatının açılışını gerçekleştiren Fethi Bey ve arkadaşları, Ege bölgesinde yeni firka teşkilatı oluşturmak amacıyla trenle Menemen, Manisa, Aydın ve Balıkesir'e hareket etmişlerdir. Fethi Bey, 13 Eylül 1930 günü Balıkesir'den Bandırma'ya geçerek İstanbul'a dönmüştür. Böylece Serbest Fırka liderinin İzmir ve Ege bölgesini kapsayan seyahati de tamamlanmıştır ${ }^{57}$.

İzmir olayları ile ilgili olarak Adalet Bakanı Mahmut (Esat Bozkurt) Bey'in 21 Eylül 1930'da Bakanlığından istifa etmesi de son derece önemlidir $^{58}$. İstifa dilekçesinde gelişen olayların Türk milleti ve inkılaplar için kötü olacağını bildiren Mahmut Bey, Serbest Fırka'nın neden olacağı olayların boyutunu ve hükümetin tutumunu da açık olarak ortaya koymaktadır ${ }^{59}$. Nitekim saltanat ve hilafet yanlılarının bu ortamı kaçırılamayacak bir şekilde firsat bilmeleri ve hemen irticai faaliyetlere girişmeleri de dikkat çekicidir.

Serbest Fırka'nın olaylı İzmir gezisinden sonra Belediye seçimlerine katılması, tartışmaları daha da alevlendirmiştir. Bu seçimlerin önemi ise, ilk defa tek dereceli seçim sisteminin uygulanacak olması ve kadınların bu seçimlerde oy kullanacak olmalarıdır. $\mathrm{Bu}$ seçimler hem Türk kadını

\footnotetext{
56 İzmir Olayları Malatya'da Serbest Cumhuriyet Fırkası'na katılımları artırmıştır. Malatya Valisi Tevfik Bey'in İçişleri Bakanlığı'na gönderdiği yazıda gelişen olaylar özetlenmektedir. Bkz., B.C.A, Dos. 7923, Fon. 30. 10. 0. 0, Yer. 78. 519. 3, (28. 9. 1930).

${ }^{57}$ Hâkimiyet-i Milliye, "Fethi Bey İstanbul'da", 14 Eylül 1930, Pazar, No. 3295, s. 1.
${ }^{58}$ Hâkimiyet-i Milliye, "Adliye Vekili'nin İstifası", 24 Eylül 1930, Çarşamba, No. 3305, s. 1. 180.

${ }^{59}$ Çetin Yetkin, Serbest Cumhuriyet Fırkası Olayı, İstanbul, Karacan Yayınları, 1982, s.
} 
açısından hem de demokrasinin topluma yerleşmesi açısından önem taşımaktadır ${ }^{60}$. Bütün olumlu ve olumsuz görüşlere rağmen Serbest Cumhuriyet Fırkası kendisi için sonun başlangıcı olan bu seçimlere katılacak ve 1930 Belediye seçimleri, Türkiye'nin siyasal yaşamında kötü İzler birakacaktır.

Serbest Cumhuriyet Fırkası seçimlere katılma kararı alınca, partide adayların çoğalmaya başladıkları görülmektedir. Belediye seçimleri tek dereceli yapılmasına karşılık bir günde tamamlanmıyor, oy hakkı bulunan seçmenlerin 10 gün içinde oylarını kullanmaları öngörülüyordu. Fakat günler geçtiği halde oyunu kullanmaya gelen Halk partililerin sayısı çok azdı. Buna karş1lık Serbest Fırka, kendini bütün bir hoşnutsuzlar zümresinin temsilcisi durumuna sokmuş ve firkaya oy vermek isteyenler adeta birbirleriyle yarışırcasına büyük bir hevesle sandık başına koşuyorlardı. Bu umulmadık ilgi ise Halk Fırkalıları endişelere sevk ediyordu ${ }^{61}$. Bütün bunların sebebini Serbest Firka'nın genel programından çok, halktaki bıkkınlık ve küskünlüğün etkisinde aramak gerekirdi. Çünkü Serbest Firka çevresinde toplanan büyük kalabalıktaki ortak noktalar, genellikle ekonomik sıkıntılar ve tek parti sistemine karşı olan tepkiden ibaretti. Bu topluluğun içinde çeşitli düşüncelerde dargınlar, öç alma heveslileri, çıkarcılar, kışkırtıcılar, gericiler ve geçim sıkıntısı çeken herkes vardı. Bununla beraber bütün bu insanları bir arada tutabilen tek şey ise özgürlüktü ${ }^{62}$.

Tüm yurtta yapılan seçimler genellikle olaylı geçmiş ve 10 günlük sürenin tamamlanmasıyla birlikte açılanan sonuçlara göre 502 belediyenin 31'ni yeni kurulan Serbest Cumhuriyet Fırkası kazanmıştır ${ }^{63}$. SCF yöneticileri bu seçim sonuçlarının gerçeği yansıttığını hiçbir zaman kabul etmemişler, onlara göre alınan sonuçlar yapılan yolsuzluk ve baskılarla elde edilmiştir. Nitekim ortaya atılan bu iddialar, basında yayınlanan demeçlerin dışında TBMM'nde iki ayrı birleşimde gündeme getirilecektir.

${ }^{60}$ Okyar, s. 509-510

${ }^{61}$ Hilmi Uran, Hatıralarım, Ankara, Ayyıldız Matbaası, 1959, s. 215-217; Cetin Özek, Gerici Akımlar ve Nurculuğun İc Yüzü, İstanbul, Ekin Basımevi, 1964, s. 183; Eskisehir Valisi Hakkı Bey'in SCF'nin yaptığ 1 propagandalarla ilgili düşünceleri için bkz., B.C.A, Dos. 7922, Fon. 30. 10. 0. 0, Yer. 78. 519. 2, (24. 9. 1930).

${ }^{62}$ Goloğlu, s. 287.

${ }^{63}$ SCF’nın kazandığı yerler şunlardır: "Armutlu (Bursa), Bademiye (İzmir), Biga (Canakkale), Bozdoğan (Aydın), Buca (İzmir), Burgaz (İstanbul), Cine (Aydın), Dikili (İzmir), Germencik (Aydın), Gördes (Aydın), Karapınar (Aydın), Keşan (Tekirdağ), Kınık (İzmir), Ladik (Samsun), Maltepe (İstanbul), Menemen (İzmir), Merzifon (Amasya), Pınarhisar (Kırklareli), Silifke (İçel), Söke (Aydın), Şereflihisar (İzmir), Sirince (İzmir), Umurlu (Aydın), Urla (İzmir), Üsküp (Kırklareli), Vize (Kırklareli) ve Yenipazar (Aydın).” Ayrıntılı bilgi için bkz., Yetkin, s. 269. 
Serbest Cumhuriyet Fırkası, 2 Ekim 1930 tarihli Meclis oturumunda konu hakkında bilgi vererek, 15 Ekim'de bir genel görüşmenin açılmasını kabul ettirmiştir ${ }^{64}$. Serbest Cumhuriyet Fırkası seçimlerde yolsuzluk yapıldı ğı iddiasında da haksız değildir. Hasan Rıza (Soyak) Bey, anılarında bu olayı şöyle açıklamaktadır ${ }^{65}$ :

\footnotetext{
"Nitekim bir gün, kendisine (Mustafa Kemal Paşa'ya) hemen hepsi CHF'nin lehinde olarak gelen seçim haberlerini arz ettiğim sirada bana 'hangi firka kazaniyor...' diye sormuş, 'tabi ki bizim firka paşam' diye cevap vermiş̧tim. Fakat Paşa gülerek 'Hayır efendim, hiç de öyle değil!! Hangi firkanın kazandığını ben sana söyleyeyim; kazanan idare firkasıdır çocuk!... Yani jandarma, polis, nahiye müdürü, kaymakam ve valiler... bunu böyle bilesin' buyurmuştu..."
}

Belediye seçimlerinde Serbest Cumhuriyet Fırkası'na oy vereceklere çıkarılan zorluklara karşı, Cumhuriyet Halk Fırkası'na oy vereceklere her türlü kolaylıklar, hatta kanunlara aykırı imkânlar dahi sağlanmıştı. Aslında seçimlerde oluşan olayların temeli daha önceye dayanmaktadır. 5 Eylül 1930 tarihinde İçişleri Bakanlığı'nın tüm valiliklere göndermiş olduğu bir genelgede $^{66}$, son zamanlarda Cumhuriyete karşı gerici ve yıkıcı faaliyetlerin yapıldığını, buna karşı görevlilerin her türlü önlemi almaları istenmektedir. $\mathrm{Bu}$ genelgede sözü edilenler, Serbest Cumhuriyet Fırkası'na karşı alınacak önlemleri içerdiği söylenebilir. Bakanlık bu genelge ile resmen memurları politik davranmaya zorlamakta, karşılarına gelen kişilerin siyasal düşünceleri doğrultusunda karar vermelerini istemektedir. $\mathrm{Bu}$ genelge seçimler öncesi hükümetin takındığı tavrı da ortaya koymaktadır. Fethi Bey bu genelgeyi ve seçimlerdeki baskıyı 6 Kasım'da Meclis'te gündeme getirerek, bu durumun kanunlara ters düştüğünü ifade etmiştir. Fethi Bey'in bu suçlamaları karşısında İçişleri Bakanı Şükrü (Kaya) Bey ise, SCF’nin ve taraftarlarının gericilerden, adi suçlulardan ve saltanat-hilafet yanlılarından oluştuğunu, bu nedenle sessiz kalmanın mümkün olmadığını, dolayısıyla 5 Eylül tarihli genelgeyi valiliklere bu amaç doğrultusunda gönderdiklerini açıklamıştır ${ }^{67}$.

\footnotetext{
${ }_{64}^{64}$ Çavdar, s. 301-302; Turan, s. 304.

65 Hasan Riza Soyak, Atatürk'ten Hatıralar, C. II, Ankara, Yapı Kredi Bankası Yayınları, 1973, s. 435.

${ }^{66}$ Genelgenin tam metni için bkz., Yetkin, s. 269-270.

${ }^{67}$ TBMM'nin 6 Kasım 1930 günlü birleşiminde Fethi Bey Meclis Başkanlığı'na șu önergeyi vermistir: "BMM Riyasetine, Son belediye intihabatında hemen her intihap dairesinde müntehiplerin serbestçe intihap haklarını kullanmalarına hükümet kuvvetleri tarafindan gösterilen mümanaat (engeller) ve müdahaleler ile umumiyetle intihap işlerine
} 
Fethi Bey'in seçimlerle ilgili olarak Meclise verdiği önerge, 15 Kasım 1930 tarihli oturumda görüşülmeye açılmış ve bu oturumda da sert tartışmalar yaşanmıştır ${ }^{68}$. Serbest Fırka'nın suçlamalarına karşılık veren CHF'li milletvekilleri de, Serbest Fırka'yı tamamen gerici bir teșkilat kurmakla suçlamışlar ve içlerinde vatan hainlerinin bulunduğunu ifade etmişlerdir.

Konya Milletvekili Refik (Koraltan) Bey; Fethi Bey'in zehirli kışkırtıcılardan nefretini belirtmediği için işin çığırından çıktığını, Cumhuriyetçilikten ve devrimlerin koruyucusu olmaktan uzaklaşıldığını, çabuk ve kolay başarı için halkın saflığından yararlanılmak istendiğini, bunun için de her çareye başvurulduğunu, özellikle vergilerin kaldırılacağının söylenerek yıkıcılıkta bulunulduğunu, şapkanın kaldırılacağından, yeni Türk harflerinin atılacağından, medreselerin açılacağından, okullara Kur'an dersleri konacağından, halifeliğin geri getirileceğinden söz edildiğini, sözlerini dinlemeyenlerin tehdit altında tutulduğunu, Halk Partililerin ise ağırbaşlı ve ciddi bir şekilde çalışarak seçimleri kazandıklarını, Serbest Partililerin hükümetten hesap isteyecekleri yerde, kendi yaptıklarını hesaba vurmalarını, bu takdirde utanmaları gerektiğini örnekler vererek anlatmaya çalışmıştır ${ }^{69}$.

Taraflar karşılıklı olarak birbirlerini ciddiyetten uzaklaşmak, sözleri değiştirmek ve demagoji yapmakla suçlamışlar ve sonuçta önergeler oya sunulmuştur. Oylama sonucu Şükrü (Kaya) Bey'in açıklamaları yeterli görülmüş ve 222 kabul oyuna karş1lı 10 ret oyu ile Fethi Bey'in önergesi reddedilmiştir $^{70}$. Seçimlerle ilgili yolsuzlukları görüşmek üzere önerge veren Fethi Bey, bu görüşmeler sonucunda suçlu duruma, daha açık bir ifade ile davaciyken davalı durumuna düşmüştür. Görüşmelerde haklılığını kabul ettiremeyeceğini anlayan Ali Fethi Bey'in partiyi kapatma kararı aldığı ve 17 Kasım 1930 günü partinin feshine ilişkin dilekçeyi İçişleri Bakanlığı'na gönderdiği görülecektir ${ }^{71}$.

karıştırılan fesat ve yolsuzluklar hakkında Dahiliye Vekili'nden istizahta bulunmak üzere müzakere açılmasını teklif ederim, efendim. Gümüşhane Mebusu Ali Fethi”' Bkz., Yetkin, s. 270-271.

${ }^{8}$ Fethi Bey'e göre; "seçmenler kütüklere yazılmamıs, kütüklerde adları yazılı olan seçmenler de nüfus tezkereleri için "yırtık var" gibi bahaneler bulunup geri çevrilerek yerlerine bașkalarına oy kullandırılmiștı. Bazı yerlerde halk, jandarma ve polisçe seçim sandiklarına yaklaştırılmamıştı. Bazl yerlerde de SCF'na oy verecek olanlar da tutuklanmışlardl. Oysa bütün bunlara karşılık CHF için elden gelen tüm kolaylıklar gösterilmişsti.” Bkz., Yetkin, s. 271.

${ }_{70}^{69}$ Goloğlu, s. 294-295.

${ }_{70}$ Goloğlu, s. 295.

${ }^{71}$ Hâkimiyet-i Milliye, "Serbest Fırka'nın Feshi Hakkında”, 19 Kasım 1930, Çarşamba, No. 3359, s. 1. 
Böylece 8 Ağustos 1930 'da temeli atılan ve 12 Ağustos 1930'da kurulan Serbest Cumhuriyet Fırkası, üç ay gibi kısa bir sürede doğmuş, büyümüş ve ölmüş, tekrar tek partili sisteme dönülmüsstü ${ }^{72}$. Partinin feshine neden olan gerekçeleri kısaca şöyle sıralamak mümkündür:

\footnotetext{
"Mustafa Kemal'in serbest Furka'dan desteğini çekmesi, Cumhuriyet Halk Firkasi'nın Mustafa Kemal'i etkilemesi, İzmir olaylarının etkisi, belediye seçimleri ve olaylar, basındaki tartışmalar, Halk Fırkası'nın tutumu ve irticai faaliyetler"
}

Serbest Cumhuriyet Fırkası'na yönelik suçlamaların başında irticai faaliyetler gelmektedir. Başta Hükümet olmak üzere, hemen hemen tüm Halk Firkası milletvekilleri, Serbest Cumhuriyet Fırkası'nın irtica yanlıları tarafindan işgal edildiğini öne sürerek, bu durumun irticai faaliyetleri körüklediğini ve olayların tek sorumlusunun Serbest Firka olduğunu belirtmişlerdir. Fakat bazı yazarlar da Serbest Cumhuriyet Fırkası'nın kapatılmasında ya da partinin içinde devrim karşıtı güçlerin yer aldığı görüşüne katılmamaktadırlar. Görüşler ne olursa olsun, 1925 Terakkiperver Cumhuriyet Fırkası olayında olduğu gibi, Serbest Cumhuriyet Firkası denemesinde de rejim ve devrim karşıtlarının hemen partiler içinde toplandığ bir gerçektir. Bu durum ise Cumhuriyetin ve devrimlerin geleceği açısından bir tehdit unsurudur. Nitekim gerek Serbest Firka, gerekse Terakkiperver Fırkası deneyimi bunu açıkça göstermiş ve 23 Aralık 1930 Menemen gericilik olayı ise bu düşüncenin doğruluğunu ispatlayacaktır.

\section{MENEMEN OLAYI (23 ARALIK 1930)}

Serbest Cumhuriyet Fırkası'nın kurulması aşamasında Mustafa Kemal'in arzu ettiği tek şey, "laik Cumhuriyet esaslarına sadık" kalınması idi. Ne var ki, 1929-1930 dünya ekonomik buhranının Ege bölgesinde yarattığı ekonomik sıkıntıdan yararlanan gerici çevreler, bu yeni partiyi firsat bilmişler ve Cumhuriyetin laik esaslarının tehlikede olduğunu gören Mustafa Kemal, bu çok partili denemeden vazgeçmiştir ${ }^{73}$. Fırsatı kaçırdığını gören irtica ise, Serbest Cumhuriyet Fırkası'nın dağılma kararı almasından otuz

\footnotetext{
${ }^{72}$ Ergün Aybars, Atatürk Çă̆daşlaşma ve Laik Demokrasi, 1. B., İzmir, İleri Kitabevi Yayınları, 1994, s. 62; Lord Kinross, Atatürk, Bir Milletin Yeniden Doğuşu, Çev. Necdet Sander, 10. B., İstanbul, Altın Kitaplar, 1984, s. 533; Ağaoğlu, s. 106.

Vehbi Tanfer, "İrtica Olayları Karşısında Atatürk", Atatürk Araştırma Merkezi Dergisi, C. VI, No. 17, (Mart 1990) s. 318.
} 
beș gün sonra tekbir sesleri ve "şeriat isteriz" sloganlarıla 23 Aralı 1930'da İzmir'in Menemen kazasında bir kere daha ayaklanmıştır ${ }^{74}$.

İslam dini fikri yargıya ve mantığa dayandığı halde, din adamları bilgi edinmek hususundaki tembellikleri yüzünden gittikçe kapkara bir cehalete düşmüş, dini kural ve görevleri, bir anlamsız şekiller yı̆̆ını haline getirmişlerdir. $\mathrm{Bu}$ hale geldikten sonra yeniliklere yönelme hususunda açılacak gediklerin, verilecek tavizlerin, kurdukları bu gerici çıkar düzenini yıkabileceği korkusu onları birbirine kenetlemiş ve kenetlenmiş cahil sözde din adamı zümresi, yıllar boyu yeniliklere akıl erdirmenin ve onları benimsemenin değil, yeniliklerden doğrudan doğruya kaçmanın, halkı bu fikirlere düşman etmenin tekniğini geliştirmişlerdir. İşte daima bu telkinlerle beslenen kara ruhlu çıkarcı cahil zümre, sayıları az da olsa zehirlerini saçmak için daima firsat gözetlemişlerdir. Gene cehaletleri yüzünden bir iki yerde kendileri gibi düşünen birkaç kişi buldular m1, bekledikleri günün geldiğini zannedip ayaklanmışlardır ${ }^{75}$.

\section{a) Olayın Çıkış Nedenleri ve Gelişimi}

Cumhuriyetin ilanıyla birlikte laik düzen ve dünya görüşü doğrultusunda gerçekleştirilen devrim hareketleri, dinsel kurallara bağlı çevrenin tepkilerine yol açmıştı. Halifeliğin kaldırılması, medreselerin, tekke, zaviye ve türbelerin kapatılması, öğretimin birleştirilmesi ve Medeni Kanunu'nun kabul edilmesi gibi değişiklikler, eski düzeni savunan ve ilk firsatta ona dönülmesini arzulayan çevreleri yeniden harekete geçirmişti. Ancak düşüncelerini açıkça söyleyerek ortaya çıkmak istemediklerinden gizliden gizliye hazırlanmaya koyulmuşlardır.

Menemen Olayı, Nakşibendi tarikatına mensup kişilerce hazırlanmıştır. Tarikatın lideri olan Şeyh Esat, tekke ve zaviyelerin kapatılmasından sonra İstanbul Erenköy'deki köşküne çekilmiş, ancak etkinliğini halife ve müritleri aracılı̆̆ 1 ile sürdürmüştü ${ }^{76}$. Kendisi, "Kutbilaktab" sanıla anılmakta ve kutupların kutbu anlamına gelen bu unvan, tarikat tarafindan her dönemde dini topluluğun maddi ve manevi başkanı olarak tanınan bir kişiye verilmektedir ${ }^{77}$. Şey Esat'ın en önemli ve çok güvendiği adamlarından birisi olan Laz İbrahim'i Manisa yöresine baş halife olarak ataması ile yörede

74 Hâkimiyet-i Milliye,"Menemen Hadisesi”, 25 Kanun-u Evvel (Aralık) 1930, Perşembe, No.3395, s. 1; Hikmet Çetinkaya, Kubilay Olayı ve Tarikat Kampları, 4. B., İstanbul, Çağdaş Yayınları, 1997, s. 16.

$7^{5}$ Neşet Çağatay, Türkiye'de Gerici Eylemler (1923'den Bu Yana), Ankara, A.Ü. İlahiyat Fak. Yayınları, 1973, s. 30-31.

${ }_{77}^{76}$ Kırçak, Meșrutiyetten Günümüze Gericilik, s.291-292.

77 Şerafettin Turan, Türk Devrim Tarihi, Yeni Türkiye'nin Oluşumu, 1923-1938, 3. Kitap, Ankara, Bilgi Yayınları, 1995, s. 310. 
tarikatın faaliyetlerinde büyük bir hareketlenme başlamıștır. Nakșibendiler gizli toplantılarla etkinliklerini sürdürürken, Muradiye Camii'nde hocalık yapmaya başlayan Laz İbrahim'in de delikanlılık çağındaki gençleri, esnaf ve çırakları etkilemeye çalıştığı görülmektedir. Özellikle ekonomik sıkıntılar nedeniyle iş bulamayan, geçimlerini sağlayamayan gençlerin tarikata girmeleri halinde büyük desteklere sahip olacakları fikri aşılanmakta ve Şeyh Esat'tan gelen ve çevreden yardım amaciyla toplanan paralar da tarikata girenlere dağıtılmakta idi ${ }^{78}$. İslamiyetin en tutucu tarikatlarından birisi olan Nakşibendilik, Şeyh Sait Ayaklanması'nda da etkili olmuş ve Şeyh Esat'ın Şeyh Sait ile ilişkisi bulunduğu anlaşılmıştır.

1930 y1lı başlarında ülkede toplumsal, siyasal ve ekonomik nedenlerle başlayan sikıntılar, Serbest Cumhuriyet Partisi'nin kuruluşu ile devrimlere karşı olan bazı kişi ve grupların, bu partiye girmelerine ya da ona yandaş görünüp kendi düşünceleri doğrultusunda çalışmalarına olanak hazırlamıştı. Yeni parti toplantılarında hükümetin açıkça suçlanması, hatta zaman zaman dinin elden gittiğinden, kadınların yüzlerinin açıldığından, zorla şapka giyildiğinden söz edilmesi, şeriat düzenine dönmek isteyenleri cesaretlendirmişti ${ }^{79}$.

İşte hükümetin güçsüz göründüğü bu ortam içinde Nakşibendi tarikat1, kendine taraftar bularak Mehdi olduğunu öne süren Giritli Derviş Mehmet ile harekete geçmeye karar vermiştir. Halifeliğin geri geldiğini ve Cumhuriyet düzeninin sona erdiğini açılamak için, İzmir ve Manisa gibi güvenlik güçlerinin hemen işe el koyabilecekleri büyük kentler değil, o yıllarda 4000 veya 5000 nüfuslu küçük bir kasaba olan Menemen seçilmişti ${ }^{80}$.

Manisa'da, kendisini ölülerin dirileceği kıyamet günü ortaya çıkacak olan "Mehdi" ilan eden Giritli Mehmet, altı arkadaşı ile "din elden gidiyor" söylemi ile harekete geçmeye karar vermiştir ${ }^{81} .7$ Aralık’ta Paşaköy'e gelerek bacanağının evinde misafir olan Giritli Mehmet ve adamları, burada silahlanmışlar ve yanlarına bir de köpek alarak, Bozalan Köyü’ne hareket

${ }^{78}$ Laz İbrahim, Menemen Askeri hastanesi imamlığından emekli olmustu. Bkz.,Turan, s. 310-311; Çetinkaya, s. 16-17; Cemalettin Saraçoğlu, "Menemen İrticai Adı Altındaki Cinayetin Esrar Dolu İç Yüzü”, Tarih Konuşuyor, C. 5, No. 29 (Haziran 1966), s. 2429-2430; Hâkimiyet-i Milliye,"Menemen Hadisesi”, 25 Kanun-u Evvel (Aralık) 1930, Perşembe, No.3395, s. 1.

${ }_{79}$ Çavdar, Türkiye'nin Demokrasi Tarihi 1829-1950, s. 302.

${ }^{80}$ Turan, s. 311.

${ }^{81} \mathrm{Bu}$ arkadaşları arasında Şamdan Mehmet, Sütçü Mehmet, Mehmet Emin, Nalıncı Hasan, Küçük Hasan ve Ramazan Efendi vardır. Bkz., Goloğlu, Devrimler ve Tepkileri 19241930, s. 303; Hâkimiyet-i Milliye,"Menemen Hadisesi”, 25 Kanun-u Evvel (Aralık) 1930, Perşembe, No.3395, s. 1. 
etmişlerdir $^{82}$. Müritlerin birisinin köyü olan Bozalan, 1924'te Rumeli'den gelen göçmenlerin yerleştirildiği bir bölgedir. Köy halkı Müslüman olmasına rağmen çoğunun din bilgisi yok denecek kadar azdır. Bu durumdan yararlanmak isteyen Derviş Mehmet ve arkadaşları köyde konaklamaya karar vermişlerdir. Fakat köy içinde rahat hareket edemediklerinden, köy yakınlarında bulunan Sünbüller Dağı'nda bir kulübe yaptırarak 15 gün kadar zikirlerine burada devam etmişlerdir ${ }^{83}$.

23 Aralık 1930 sabahı erkenden Menemen'e gelen Derviş Mehmet ve müritleri, tekbirler getirerek çarşı içindeki Müftü Camii'ne yönelmişlerdir. Silahlı olarak camiye giren Derviş Mehmet, sabah namazına gelmiş 8-10 yaşlı kişiye kendisini Mehdi olarak tanıtmış ve dini korumaya geldiğini, 70 bin kişilik halife ordusunun da yakında gelip kendisiyle birleşeceğini öne sürmüştür. Arkasından camideki "sancak- $\iota$ şerif" denilen üzerinde "La ilahe İllallah İnna Fetahneke" yazılı yeşil bayrağ ${ }^{84}$ alan Derviş, öğleye kadar bu sancağın altında toplanmayanların kılıçtan geçirileceği tehdidini savurmuştur. Buradan Belediye Meydanı'na yönelen Derviș ve müritleri, şeriatın simgesi sayılan bu bayrağı bir çukura diktirerek etrafında zikredip tekbir getirmeye başlamışlardır. $\mathrm{Bu}$ arada sabah namazından çıkan ve dükkânlarını açmaya gelen halk da meydanda toplanmaya başlamıştır. Derviş Mehmet toplanan halka, "Ey Müslümanlar, ne duruyorsunuz? Halife Abdülmecit sınıra geldi, sancak-ı şerif çıktı, gelin altında toplanalım, şeriat isteyelim" şeklinde çağrılar yapıyor ve propagandasını devrimler üzerinde yoğunlaştırıyordu. Şapka giyenlerin kâfir olduğunu, yakında yine fes giyileceğini ileri sürüyordu. Meydana gelenlerin bir kısmı bu çağrı üzerine onlara katılıp zikre başlamış ve kısa süre içinde Derviş'in yanındakiler 100 kişiye kadar ulaşmıştır ${ }^{85}$.

$\mathrm{Bu}$ arada bazı duyarlı vatandaşların olayı emniyet kuvvetlerine haber vermesi üzerine, olay yerine ilk olarak jandarma yazıcısı Ali Efendi

${ }^{82}$ Giritli Derviş Mehmet yolda yanlarına almış oldukları köpeğe Kıtmir adını vermişlerdir. Kitmir, Eshhab-1 kehf efsanesinde yol gösterici sanılan köpeğin adıdır. Bkz., Çetinkaya, s. 18; Hâkimiyet-i Milliye, "Menemen'de Tahkikat Ehmiyetle Devam Ediyor", 27 Kanun-u Evvel (Aralık) 1930, Cumartesi, No. 3397, s. 1-3.

${ }^{83}$ Sanıklardan birinin sonraki sorgulamalarında açıkladığına göre, Menemen'e gidip Hoca Saffet Efendi'de bir gece kalıp ögütler alacaklar ve oradan İstanbul'daki Kutbilaktap Hoca Esat Efendi'ye telgraf çekip, hükümete el koyacak ve tüm tekkeleri açma kararı almışlard1. Bkz. Goloğlu, s. 304 .

${ }^{84}$ Sehit Kubilay Bey'in kesilmiş başının takıldığ sancak için bkz.; Emniyet Genel Müdürlüğ̈̈ Polis Dergisi, "Cumhuriyetin 75. Yıldönümünde Polis Arşiv Belgeleriyle Gerçekler", Özel Sayı, No. 129, (Eylül 1998), s. 75.

${ }^{85} \mathrm{O}$ sırada oradan omzunda çapasıyla işe gitmekte olan bir işçiyi yoldan çevirip çukur kazdırmışlar ve oraya yeşil bayrağı dikmişlerdir. Asiler ellerinde silahları olduğu halde bayrağın etrafında dönerek tekbir getirip zikretmeye başlamıslardır. Bkz., Hâkimiyet-i Millive, "Menemen'de Tahkikat Ehmiyetle Devam Ediyor", 27 Kanun-u Evvel (Aralık) 1930, Cumartesi, No. 3397, s. 1-3; Çăgatay, s. 31; Turan, s. 312; Çetinkaya, s. 20. 
gelmiștir. Giritli Mehmet'ten ne yapmak istediğini soran Ali Efendi, "Sen git de komutanını yolla" cevabını alınca, durumu hemen Bölük Komutanı Fahri Bey'e bildirmiştir. Fahri Bey'in doğruca evinden olay mahalline gelerek Derviş Mehmet ile görüştüğü ve amacını öğrenmek istediği görülmektedir. Derviş Mehmet ise Bölük Komutanı Fahri Bey'e, kendisinin mehdi olduğunu, dini yaydığını ve kendisine karşı koyamayacağı tehditlerini savurarak hakaretler etmiştir. Bu gelişmeler üzerine Bölük Komutanı tedbir almak üzere olay yerinden geri çekilmek zorunda kalmıştır. Bu olaydan cesaret alan Derviş Mehmet'in halk üzerinde etkisi de her geçen saat hızla $\operatorname{artmıştır~}^{86}$.

Jandarma Bölük Komutanı, telefonla 43. Alay'dan askeri yardım istemiş ve Alay Komutanlığı da I. Tabur, 3. Bölük Komutanı İzmirli Hüseyin oğlu yedek subay Asteğmen Kubilay'ı bir müfreze ile olay yerine göndermiştir. Girit'ten göç eden bir ailenin çocuğu olan 1906 doğumlu Kubilay'ın asıl adı Mustafa Fehmi'dir. Terzi çıraklı̆̆ 1 yaparken öğretmen olmayı istemiş, sınavları kazanarak 1926'da Bursa Öğretmen Okulu'ndan mezun olmuştu. Heyecanlı, atak bir genç olarak tanınmakta ve Atatürk'ün öncülük ettiği devrimlerin ateşli savunucularından birisi idi. Türk tarihinden de esinlenerek adına Kubilay’ı da eklemiş ve öylece anılmıştı. Alay Komutanlığı'ndan kendisine verilen görev üzerine, kışladan çıkarken silahını bile almayan ve emrindeki takımın erlerinde ise sadece manevra mermileri bulunan Kubilay, süratle olay yerine hareket etmiştii ${ }^{87}$.

Olay yerine gelen Asteğmen Kubilay, erleri kalabalığın yanında bırakıp yalnız başına isyancıların yanına gitmiş ve Derviş Mehmet'in yakasından tutarak sert bir sesle hemen silahlarını bırakıp teslim olmalarını istemiştir. $\mathrm{Bu}$ kez işin sıkıya geldiğini gören Derviş Mehmet ise tabancasını ateşleyip genç Asteğmeni yaralamıştır ${ }^{88}$. Komutanlarının yaralandığını gören askerler manevra mermileri ile ateş açmışlar fakat mermilerin kendilerine bir şey yapmadığını gören Mehmet ve müritleri daha da cesaretlenmişlerdir. Bu kargaşa anında yaralanan Kubilay, yerden kalkıp yakındaki Gazez Camii avlusuna doğru koşmaya başlamış, ancak oraya ulaşınca tekrar yığılıp

${ }^{86}$ Goloğlu, Devrimler ve Tepkileri (1924-1930), s. 304; Mete Tunçay, Türkiye Cumhuriyeti'nde Tek-Parti Yönetiminin Kurulması (1923-1931), 3. B., İstanbul, Cem Yayınevi, 1992, s. 293-294.

87 Asteğmen Kubilay, emrindeki 26 kişilik müfreze ile olay yerine süratle intikal edebilmek amacıyla kışla arkasındaki yamaçlardan, kestirme yollardan hızla geçmiş ve meydana yakın sokakların birinde askerlerine süngü taktırmıștır. Ayrıntılı bilgi için bkz., Hâkimiyet-i Milliye, "Menemen'de Tahkik Heyeti Yeni Tevkifat Yaptı. Yakalanan Hacı ve Hocalar", 28 Kanun-u Evvel (Aralık) 1930, Pazar, No. 3398, s. 1-3.

${ }^{88}$ Bu kurşun Kubilay'ın sağ omzundan girip arkasından çıkmıștır. Asteğmen Kubilay'ın silahla yaralanması ile ilgili geniş bilgi için bkz.; Genelkurmay ATASE Başkanlığı Arşivi, "Menemen Olayı Keşif Zabıt Varakası", 23 Aralık 1930, D. 1, F. 1-1. 
kalmıștır. Ne askerden ne de halktan bir yardım gelmediğini gören Derviș Mehmet müritleri, bunun üzerine yeşil bayrağın dibindeki torbasından testere ağızlı bir bağ bıçağı çıkararak Kubilay'ın üzerine saldırmışlar ve kısa bir mücadeleden sonra başını gövdesinden ayırmışlardır ${ }^{89}$. Bununla da yetinmeyen Derviş Mehmet, Kubilay'ın kanını avuçlarıyla içmiş ve kesik başını bir iple sancağın direğine bağlayarak Menemen'i dolaşmaya başlamıştır ${ }^{90}$. Kalabalığın tekbir sesleri arasında Derviş Mehmet, "Kalkın ahali, Müslümanlı̆ğ kurtaralım" diye bağırmaktadır ${ }^{91}$.

Silah sesini duyurarak olaya müdahale etmek isteyenler yalnızca genç mahalle bekçileri Hasan ve Şevki Bey olmuştur. İsyancılarla Bekçilerin çatışmasında isyancılardan birisi öldürülmüş, fakat iki bekçi de isyancılar tarafindan şehit edilmişlerdir ${ }^{92}$. Bu sırada Alay Komutanlığ 1 , olayın bu boyuta erişmesinden endişelenerek daha güçlü bir birliği asilerin üzerine göndermiş ve komutanın "teslim ol" çağrısına, asiler "bize kurşun işlemez" diye ateşle karşılık vermişlerdir. Çıkan silahlı çatışmada Mehdi Giritli Derviş Mehmet, Sütçü Mehmet ve Şamdan Mehmet ölmüşler, yaralanan Emrullah oğlu Mehmet ile Hasan adında diğer iki kişi ise, sokak aralarına kaçarken yakalanmışlardır ${ }^{93}$.

${ }^{89}$ Kesilme keskin ağızlı, bir tarafı künt, oluklu ve takriben $25 \mathrm{~cm}$. uzunluğunda bir bıçak ile yapılmıştır. Ayrıntılı bilgi için bkz., Emniyet Genel Müdürlüğü Polis Dergisi, "Cumhuriyetin 75. Yıldönümünde Polis Arşiv Belgeleriyle Gerçekler", Özel Sayı, No. 129, (Eylül 1998), s. 67.

90 Olayın tanıkları mahkeme kayıtlarına da geçen ifadelerinde yaşananları şöyle anlatmaktadır: "... Ahali gittikçe büyüyordu. Yirmi dakika geçti. Birdenbire meydanı otuz kırk nefer silahlarına süngü takarak abluka etti. İçlerinden genç bir zabit ileri atıldı. Mehdinin yakasını tuttu ve şiddetle sarstı. Mehdi, genç zabiti silkeleyip yere attı ve elindeki silahı çevirerek zabite ateșledi. Yaralı zabit, yarasının ağırlı̆̆ına rağmen ayă̆a kalktı ve meydandan çekildi. Halktan bir kısım bu esnada uzun uzun el çırparak alkışliyor ve Allah Allah diye bağırıyordu. Aradan on beş dakika geçti. Asilerden biri, Mehdi'nin yanına gelerek, zabitin cami avlusunda yattığını haber verdi. Bunun üzerine Mehdi yanındaki birinden bıçağl alarak bir arkadaşlyla cami avlusuna girdi. Biz uzaktan duyduk. Yaralı gencin sesi yalvartyordu. 'Kesmeyin beni!' Mehdi ise; 'Anlaşıldl, anlaşıldl. Sen daha çocuksun. Kesilmekten korkuyorsun. Seni yüzükoyun yatırayım da görmeyesin... '. Mehdi, genç ve yaralı zabiti yüzükoyun yatırdıktan sonra bir ayağın yaralı omzuna koydu, bir eliyle saçlarından tutup Kubilay'ın diri diri boğazını kesti. Sonra da elindeki bașı caminin önündeki büyükçe bir taşın üzerine koyarak 'Gördünüz mü? Kâfirlerin akıbeti iş̧te budur' diye bağırmaya başladı. Sonra, 'Getirin bir ip!' diye bağırdl. Meydanda toplanan halktan biri dükkânına koşarak ip getirdi. Kesilmiş başı bayrağın tepesine bağladılar...” Bkz., Hâkimiyet-i Milliye, "Korkunç Bir Sahne, İrtica Çetesi Kubilay'ın Başını Nasıl Kesti.”, 29 Kanun-u Evvel (Aralık) 1930, Pazartesi, No. 3399, s. 1.

${ }_{91}$ Cavdar, Türkiye'nin Demokrasi Tarihi 1829-1950, s. 302.

92 Turan, s. 313; Goloğlu, Devrimler ve Tepkileri (1924-1930), s. 305.
93 43'ncü Piyade Alay Komutanlığ 1 , asileri etkisiz hale getirmek amacıyla Yüzbaș Ragıp (Çaldıran) ile Yüzbaşı Abdülbahri Bey'in komutalarında makineli tüfekle takviyeli iki bölügü süratle olay mahalline sevk etmiştir. Bkz., Hâkimiyet-i Milliye,"Menemen Hadisesi", s. 1-4; Hâkimivet-i Milliye, "İrtica Hadisesi Müretteptir ve Sumullüdür. Fırka Grubunda Hadise Üzerinde Heyecanlı Müzakerat Oldu”, 31 Kanun-u Evvel (Aralık) 1930, Çarşamba, No. 3401 , s. 1. 


\title{
b) Olayın Sonuçları
}

Menemen'de yaşanan bu olay, tam anlamıyla laik hukuk düzenine ve Cumhuriyete karșı gerici bir ayaklanma niteliğinde gerçekleşmiştir. Cumhurbaşkanı Mustafa Kemal, bu irticai olayı Edirne'de öğrenmiş ve çok kızmıştır. 27 Aralık'ta ise TBMM Başkanı Kazım (Özalp), İçişleri Bakanı Şükrü (Kaya) Beyler ile Genelkurmay Başkanı Mareşal Fevzi (Çakmak), İkinci Ordu Komutanı Fahrettin (Altay) Paşalar, İstanbul'a giderek Dolmabahçe Sarayı'nda Gazi Mustafa Kemal'e olay hakkında ayrıntılı bilgi vermişlerdir $^{94}$.

Cumhurbaşkanı Mustafa Kemal Paşa, 28 Aralık 1930'da orduya yayımladığı başsağlığı bildirisinde ayaklanmacılara ve onları alkışlayan kişilere duyduğu kızgınlığı şu sözlerle ifade etmektedir ${ }^{95}$ :

\begin{abstract}
“Menemen'deki gericilik olayında Yedeksubay Asteğmen Kubilay Bey'in görev yaparken uğradı̆̆ akıbetten ötürü, Cumhuriyet Ordusu'na başsağlığı dilerim. Kubilay şehit olurken gericilerin gösterdiği vahşet karşısında Menemen'deki halktan bazılarının alkış tutarak olayı uygun bulduklarını belli etmeleri, bütün Cumhuriyetçiler ve vatanseverler için utanılacak bir durumdur. Vatanı savunmak için yetiştirilen, her türlü iç politikanın ve anlaşmazlığın dişında ve üstünde saygıdeğer bir durumda bulunan Türk subayının, gericiler karşısındaki yüksek görevinin vatandaşlarca yalnızca saygı ile karşılandığına şüphe yoktur...

"Büyük ordunun kahraman genç subayl ve Cumhuriyetin mefkûreci ögretmen topluluğunun klymetli üyesi Kubilay'ın temiz kanı ile Cumhuriyet, canlıllğını tazelemiş ve kuvvetlendirmiş olacaktır."
\end{abstract}

Gazi Mustafa Kemal Paşa'nın başsağlı̆̆ı bildirisini Genelkurmay Başkanı Mareşal Fevzi (Çakmak) Paşa, şu tamimle orduya tebliğ etmiștir ${ }^{96}$ :

"Zabit Vekili Kublay Beyin feci bir surette vuku bulan şehadeti münasebetile Reisicumhur Hazretlerinin ordumuza taziyetnameleri sureti aynen yukartya dercedilmiştir. Bütün kıtaat ve müessesatta umum zabit ve

\footnotetext{
${ }^{94}$ Hâkimiyet-i Milliye, "Gazi Hz. Kublay Bey'in Şehadeti Dolayısıyla Cumhuriyet Ordusunu Taziyet Etti.”, 29 Kanun-u Evvel (Aralık) 1930, Pazartesi, No. 3399, s. 1.

5 Hâkimiyet-i Milliye, "Kazım ve Fevzi Paşalar İstanbul'a Gitti. Paşalar Doğruca Dolmabahçe'ye Gittiler.”, 28 Kanun-u Evvel (Aralık) 1930, Pazar, No. 3398, s. 1; Atatürk'ün Tamim, Telgraf ve Beyannameleri, C. IV, s. 601.

96 Hâkimiyet-i Milliye, "Müşür Paşa Ordunun Layezal Rabıtasını Reis-i Cumhur Hazretlerine Bizzat Arz Etti.”, 29 Kanun-u Evvel (Aralık) 1930, Pazartesi, No. 3399, s. 1.
} 
neferler muvacehesinde merasimi mahsusa ile okunmasını tamimen tebliğ ederim. Yüksek ordumuz hakkında her vakit ızhar buyurulan ve bu defa da pek âli bir surette tecelli eden bu muhabbet ve hissiyatı aliyeye karşı ordumuzun lâyezal rabıta ve şükranlarl Reisicumhur Hazretlerine bizzat arzolunmuştur. Bu kahraman arkadaşımızın şehadetinden dolayı teessürlerimi ifade ederken, bu aziz şehidin ruhunu tebcilen zati taziyetlerimin de bütün ordu arkadaşlarıma iblăğını ayrıca rica ederim."

Bu gerici olay, Atatürk'ten başlayarak hükümette ${ }^{97}$, TBMM'de olduğu kadar basında ve kamuoyunda sert tepkiler doğurmuştur. 31 Aralık 1930'da Başbakan İsmet (İnönü) Paşa'nın başkanlığında toplanan Bakanlar Kurulu, Menemen Olayı'nı sosyal düzene karşı bir ayaklanma niteliğinde görerek, "suçun Cumhuriyete karşı geniş kapsamlı bir düzene dayandiğı hakkında kesin belgeler olduğu" gerekçesiyle Menemen ile Manisa ve Balıkesir merkez ilçelerinde bir ay süre ile sıkıyönetim ilan edilmesine karar vermiş ve Sıkıyönetim Komutanlığı'na ise 2. Ordu Komutanı Fahrettin (Altay) Paşa, Divan-1 Harp Reisliği'ne 1. Kolordu Komutan Vekili Muğlalı Mustafa Paşa atanmıştır $^{98}$. Yine aynı gün Denizli Milletvekili Mazhar Müfit (Kansu) ve 43 milletvekili tarafından, olayla ilgili olarak bir önerge hazırlanmış ve Meclis'e verilmiştir. Nitekim Hükümetin tavrının ne olacağı ve ne tür tedbirler alınacağına dair önerge ile konu 1 Ocak 1931 tarihinde TBMM gündemine taşınmıştır ${ }^{99}$ :

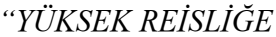
"Menemen'de tahaddüs eden irtica vak'ast Meclisi derin teessürlere garketmiş ve hadisenin doğrudan doğruya cumhuriyete müvecceh bir suikast olduğu anlaşılmakta bulunmuştur. Kahraman bir zabitimizin maruz kaldı ̆̆ feci akıbet, haydutların bir kaç serseri veya esrarkeşten ibaret olmayıp mürettep ve şümullü ve irtica hareketi olduğu kanaatini vermiştir. Binaenaleyh Meclis büyük bir hassasiyet ve kat'iyetle vazifesini ifaya hazırdır. Evvelâ Hükümetçe hadise hakkında şimdiye kadar yapılan

97 İçişleri Bakanı Şükrü Kaya olay üzerine Menemen'e gelmiş ve üç şehidin kabri başında şu konuşmayı gerçekleştirmiştir: “...Burada şerefle yatan bu şehitler, cehalet ve taassubun feci kurbanlarıdır. Size bunların huzurlarında taziyetlerimi ve teessürlerimi beyan ederim..." Bkz., Hâkimiyet-i Milliye, "Dahiliye Vekilinin Nutku.", 30 Kanun-u Evvel (Aralık) 1930, Salı, No. 3400, s. 3.

Hâkimiyet-i Milliye, "Divanı Harp Teşekkül Etti ve Örfi İdare Amirliği'ne Fahrettin Paşa Tayin Edildi”, 2 Kanun-u Sani (Ocak) 1931, Cuma, No. 3403, s. 1,4.

Denizli Milletvekili Mazhar Müfit Kansu'nun olayla ilgili Hükümetin ne gibi tedbirler aldığına dair 31 Aralık 1930 tarihli sözlü önergesi için bkz., B.C.A, Dos. 6755, Fon. 30. 10. 0. 0, Yer. 8. 48. 9, (31. 12. 1930). 
tahkikat safahatile netayicinin neden ibaret olduğu ve ne gibi tedbirler alındı $\breve{l}$ ve alınacă̆ hakkında Başvekil Paşa'nın Mecliste şifahen izahat ve malûmat vermesi için işbu sual takririmiz takdim kilındı efendim."

1 Ocak 1931'de Meclis'te soru önergeleriyle ilgili olarak Başbakan İsmet (İnönü) Paşa, Kubilay'ın şehit edilmesinden duyduğu üzüntüyü dile getiren, dinin siyasete alet edilmesinden ve bunun sakıncalarından bahseden şu konuşmayı gerçekleştirmiştir ${ }^{100}$ :

"Hepimiz ailelerimizde yetiştirdiğimiz çocuklardan bir kurban vermiş olduk. Hepimiz bu kurbanda vatan için büyük ümitlerle yetiştirilen genç ve kahraman zabitlerden vatandaş eliyle feda edilmiş bir şehit gördük...

"Meselenin dini siyasete alet ittihaz eden safhasina nazar-i dikkatimizi tevcih etmeliyiz. Siyasette aranılan şey bir takım adamların ve bilhassa politikactların dini, ahar fertlerin hürriyeti aleyhine ve devletin kanunlart aleyhine bir vasita-i taarruz olarak kullanmamalarıdır. Memnu olan şey budur. Hadisede görüyoruz ki, cehaletleri bir kısminın cehaleti olabilir. Bir kisminin bilerek tasmimleriyle ve cümlesi din elden gidiyor bahanesiyle bu adamlar mütearriz bir istikamete sevk olunuyorlar. Bu hareketler devlet ve Cumhuriyetaleyhine fiilen tecavüze kast mahiyetindedir."

Başbakan İsmet Paşa konuşmasında, Bakanlar Kurulu'nun bir gün önce aldığı sıkıyönetim kararının gerekçelerini de açıklamış ve bu olayı üç aylık bir hazırlığın sonucu olarak göstermiştir. "Bu olay yüzyıllardır dini politikaya alet eden tüm hareketlerin bir yinelenmesidir. Bu zavallilar laikliğe karşı gelerek şeriat istemektedirler. Gerçekte ise çıkarlarını kaybetmişlerdir. Onu istiyorlar..." sözleriyle olayın muhalefetle (SCF) ilișkisinden söz ederek tahminlerde bulunmuștur ${ }^{101}$.

Başbakanın konuşmasından sonra, önerge sahibi olarak Denizli Milletvekili Mazhar Müfit Bey söz almış ve konu ile ilgili şu konuşmayı yapmışıır ${ }^{102}$ :

${ }^{100}$ Hâkimiyet-i Milliye, "Başvekil Paşa İrtica Hadisesine Dair Sual Takririne Cevap Verdi" 3 Kanun-u Sani (Ocak) 1931, Cumartesi, No. 3404, s. 1,3.

${ }_{101}$. A.g.g., s.3.

${ }^{102}$ Hâkimiyet-i Milliye, "Mazhar Müfit Bey'in Beyanatı", 3 Kanun-u Sani (Ocak) 1931, Cumartesi, No. 3404, s. 3. 


\begin{abstract}
"Arkadaşlar, Menemen Hadisesi hakkında vuku bulan sualimize Başvekil Paşa Hazretlerinin verdikleri cevaptan, beyanat ve izahatından Menemen hadisesinin ne suretle zuhur ve nasıl idare edildiğini ve tahkikatın neticesine ittıla ettik. ...Muhterem şehit Kubilay'ın ruhu müsterih olsun, onun ideali, onun mefkûresi olan Cumhuriyet ve inkılâbını kimse tevakkuf ettiremez. O daima yürüyecektir ve daima yürüyecektir. Çünkü efendiler, Kubilay gibi içinde binlerce kişi bulunan ve daima o karayılanın girtlağına sarllacak ve daima ezecek ve zehrini saçamayacak bir hale sokacak bir gençlik vardır. Bütün vatandaşlar müsterih olsun ki Cumhuriyet rejimi ve inkllâp, bu, tevkif edilemez, yürüyecektir, efendiler "
\end{abstract}

Menemen Olayı ile ilgili sıkıyönetim kararını onaylayan Meclis, Korgeneral Muğlalı Mustafa Paşa başkanlığında bir askeri mahkemenin kurulmasını da uygun görmüştür. Bu arada 7 Ocak 1931'de Çankaya'da, Mustafa Kemal Paşa başkanlığında, Başbakan İsmet Paşa, Meclis Başkanı Kazım (Özalp) Paşa, Sıkıyönetim Komutanı Fahrettin (Altay) Paşa, İçişleri Bakanı Şükrü (Kaya) ve Milli Savunma Bakanı Zekâi (Apaydın) Beylerin katıldıkları bir toplantı yapılmış ve Menemen Olayı bütün yönleriyle ele alınmıştır. Bu toplantıda olayın gerici nitelikte, düzenli ve siyasi olduğu görüşüne varılarak ilgililerin en sert şekilde cezalandırılması istenmiştir.

15 Ocak 1931'de başlayan Divan-1 Harp Mahkemesi'ndeki duruşmalar sürecinde, olaya doğrudan veya dolaylı katılan sanıklar, "Anayasayı cebren tağyir, eyleme iştirak, azmettirme ve Mehdi Mehmet'in, mehdiliği için harekete geçtiğini bildikleri halde zamanında Hükümete haber vermedikleri, tekkelerin seddinden sonra ayini tarikat icra ettikleri" suçlamalarıla yargılanmıştır ${ }^{103}$.

General Mustafa Muğlalı başkanlığında kurulan Divan-1 Harp Mahkemesi'nde 24 Ocak 1931 günü iddianamenin okunmasiyla yargılama süreci sona ermiş ve 29 Ocak 1931 günü Mahkeme, çoğu Giritli ve Rumeli göçmeni olan 105 sanıktan 37 sanık hakkında ölüm ve 41 sanık hakkında da çeşitli hapis cezaları vermiştir ${ }^{104}$. Bu arada yaşları küçük olan bazı sanıkların cezalarının hapse çevrildiği görülmektedir. 6 sanığın ölüm cezası yaş haddi nedeniyle 24 yila (idama bedel hapis cezasına) ${ }^{105}$, diğer sanıklardan 6'sına

${ }^{103}$ Hâkimiyet-i Milliye, "Menemen'de Divanı Harp Bugün İşe Başladı", 16 Kanun-u Sani (Ocak) 1931, Cuma, No. 3417, s. 1, 3.

Hâkimiyet-i Milliye "Divanı Harbin Karar1-Karar Millet Meclisi'ne Bildirildi", 2 Şubat 1931, Pazartesi, No. 3434, s. 1,4.

İ́dam cezasından 24 yıl hapis cezasına mahkûm edilen sanıklar şunlardır: "1Manisa'dan Nalıncı Hasan (20) yasında, 2-Manisa'dan Coban Ramazan (20) yasında, 3Manisa'dan Giritli Küçük Hasan (17) yaşında, 4-Menemen'den Harputlu Ömer oğlu Mehmet (65) i mütecaviz (65 yaşını geçmiş), 5-İzmir’den Laz Mehmet Ali Hoca (65) i mütecaviz, 6- 


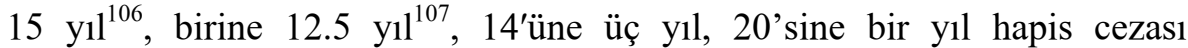
verilmiş ${ }^{108}$ ve 27 sanık ise beraat etmiştir ${ }^{109}$.

Divan-1 Harp Mahkemesi'nin kararı, 31 Ocak 1931'de TBMM'ne sunulmuş ve aynı gün Adalet Komisyonu'nda görüşülmeye başlanmıştı1 ${ }^{110}$. Komisyon, Teşkilat-1 Esasiye Kanunu'nun 26. maddesine dayanarak 31 ölüm cezasından $28^{\prime}$ ini onaylamış ${ }^{111}$ ve 2 kişinin ölüm cezasını da 2 yıl

Erbilli Şeyh Esat (65)i mütecaviz.” Bkz., Hâkimiyet-i Milliye, "Divanı Harbin Kararı-Sinleri İcabı İdama Bedel 24 Sene Hapise Mahkûm Edilenler", 2 Şubat 1931, Pazartesi, No. 3434, s. 4.

10615 yıl ağır hapis cezasına mahkûm edilen sanıklar şunlardır: "1-Horus köyünden Selâhattin oğlu Naşit, 2-Horus köyünden Yakup oğlu Ali, 3-Horus köyünden Muhittin oğlu Ali, 4-Horus köyünden Hasan oğlu Ahmet, 5-Horus köyünden Necip oğlu Mevlût, 6-Horus köyünden Ragıp oğlu Osman" Bkz., Hâkimiyet-i Milliye, "Divanı Harbin Kararı-Derecat Muhtelifede Hapis Ağır Hapis Cezalarına Mahkûm Edilenler”, 2 Şubat 1931, Pazartesi, No. 3434, s. 4.

${ }^{07}$ Horus köyünden Mümtaz oğlu Hașim 65 yaşını mütecaviz olduğundan 12,5 y1l ağır hapis cezasına mahkûm edilmiştir. Bkz., Hâkimiyet-i Milliye, "Divanı Harbin Kararı-Karar Millet Meclisi'ne Bildirildi”, 2 Şubat 1931, Pazartesi, No. 3434, s. 4.

${ }^{08}$ Hapis cezası alan sanıkların isim listesi için bkz., Hâkimiyet-i Milliye, "Divanı Harbin Kararı-Üçer Sene Hapse Mahkûm Edilenler-Birer Sene Hapse Mahkûm Edilenler", 2 Şubat 1931, Pazartesi, No. 3434, s. 2.

${ }^{109}$ Beraat edenler şunlardır: "Mehmet Emin Validesi Hasbiye, Hemşiresi Halide Fatma, Refikası Emine Mehdinin Kayınvalidesi Rukiye, Manisa'dan Hasan Ailesi Fatma, Menemen'de Saffet Hoca, Menemen'de Hüseyin oğlu Rasim, Menemen'den Tütüncü Haydar, Menemen'den Gözlükçü Ali, Menemen'den Raşit oğlu İbrahim, Menemen'den Mazlumaki oğlu Rasim Ali, Menemen'den İbrahim oğlu İsmail, Menemen'den Berber Hafiz Ahmet, Bozalan'dan Mustafa oğlu Mustafa, Bozalan'dan Ali oğlu Mustafa, Manisa'dan Hüseyin oğlu Keçeci Süleyman, Manisa'dan Fırıncı Mustafa oğlu Ahmet, Manisa'dan Ahmet oğlu Hüseyin Mazlum, Manisa'dan Hasan oğlu Katmerli Mehmet, Manisa'dan Tütüncü Hasan oğlu Hasan, Manisa'dan Ahmet oğlu Halil, Manisa'da Mustafa oğlu Mehmet, Manisa'dan Bıçakc1 Mustafa, Manisa'dan Çulha Mehmet Çavuş, Manisa'dan Hoca Hakkı, Horus köyü'nden Sadettin oğlu Nurettin". Ayrıntılı bilgi için bkz., Hâkimiyet-i Milliye, "Divanı Harp İlk Kararını Verdi. Suçsuz Olan Üç Kişi Beraat Etti.”, 29 Kanun-u Sani (Ocak) 1931, Perşembe, No. 3430, s. 1; Hâkimiyet-i Milliye, "Divanı Harpte Suçsuz Olanlar Dün Beraat Etti. Beraat Edenler", 30 Kanun-u Sani (Ocak) 1931, Cuma, No. 3431, s. 1-2.

110 Hâkimiyet- $i$ Milliye, "Divanı Harbin Kararı-Karar Millet Meclisi'ne Bildirildi", 2 Şubat 1931, Pazartesi, No. 3434, s. 1,4.

111 İdamla cezalandırılan ve infazı gerçekleştirilen sanıklar şunlardır: "1-Manisa'dan Manifaturacı Osman, 2-Manisa'dan Hafız Cemal, 3-Manisa'dan Tabur İmamı İlyas Hoca, 4Manisa'dan Hacı Ali Paşazade Ragıp Bey, 5-Manisa'dan Şeyh Hafiz Ahmet, 6-Manisa'dan Giritli İbrahim oğlu İsmail, 7-Menemen Bozalan Köyü'nden Koca Mustafa, 8-Menemen Bozalan Köyü'nden Hacı İsmail, 9-Menemen Bozalan Köyü’nden Hacı İsmail oğlu Hüseyin, 10-Erbilli Seyh Esat oğlu Mehmet Ali Hoca, 11-Menemen'den Cumayibalalı Veli oğlu Ramiz, 12-Menemen'den Çitaklı Molla Hüseyin, 13-Menemen'den Hayim oğlu Jozef, 14Menemen'den Şimilli Mehmet, 15-Menemen'den Arnavut Yusuf oğlu Kâmil, 16Menemen'den Kerim oğlu İbrahim, 17-Menemen'den Selim oğlu Boşnak Abbas, 18Alaşehir'den Şeyh Ahmet Muhtar, 19-Manisa'dan Mutaf Süleyman, 20-Manisa Hastanesi imamlığından mütekait Laz İbrahim Hoca, 21- Manisa'dan Emrullah oğlu Mehmet Emin, 22Manisa'dan Kahveci Mustafa, 23-Manisa'dan Tatlıcı Hüseyin, 24-Manisa'dan Topçu Hüseyin, 25-Manisa'dan Eskici Hüseyin Ali, 26-Manisa'dan Keçeci Himmet oğlu Süleyman Çavuş, 27-Menemen'den Yahya oğlu Hüseyin, 28-Menemen'den Çingene Mehmet oğlu Hüseyin." Ayrıntılı bilgi için bkz., Hâkimiyet-i Milliye, "Divanı Harbin Kararı-İdama Mahkûm Edilenler”, 2 Şubat 1931, Pazartesi, No. 3434, s. 4; Emniyet Genel Müdürlügü Polis 
hapis cezasına çevirmiştir. Bir kișinin cezası da (Bozalan köyünden Görüceli Abdülkerim) infazdan önce eceliyle ölmesi nedeniyle kaldırılmıştır ${ }^{12}$. TBMM Genel Kurulu, 3 Şubat 1931'de Menemen sanıklarının cezalarını onaylamış ve ölüm cezaları 3 Şubat 1931 gecesi Menemen'de yerine getirilmiştir $^{113}$.

Divan-1 Harp Mahkemesi'nde yapilan yargilamalar sonucunda, Laz İsmail'in İstanbul'daki Nakşibendi şeyhleri ile ilişkisi ortaya çıkmıştır ${ }^{114}$. Şeyh Hoca Esat, Şeyh Halit, Hoca Saffet ve Hoca Esat'in oğlu Mehmet Ali'nin ayaklanmanın hazırlanmasında etkin rol oynadıkları anlaşılmıştır. Menemen Olayı'nda bütün bölge halkının birlikte ayaklanması ya da politik merkezlerden gelen emirle düzenlenmiş bir ayaklanma niteliği görülmemiş, hatta sanıklardan bazılarına yöneltilen sorulara alınan cevaplardan, bunların iktidar partisine mensup oldukları anlaşılmıştı. Bunun üzerine olayın gerici niteliği üzerinde durulmuş ve bu kaynaktan doğduğu anlaşılan olayın sanıklarının Manisa Hastanesi imamlığından emekli Laz İbrahim ile olan ilişkileri incelenmiş, onun da İstanbul Cibâli Tütün Fabrikası'nda Enfiye (Tütün Tozu) Eksperi olan Mehmet Ali ile tanışıklığı dikkati çekmiş ve Mehmet Ali'nin babasının Erenköy'deki köşkünde oturan Nakşibendi Şeyhi Kutbilaktap Erbilli Hoca Esat Efendi olduğu anlaşılmıştır. Olayın büyümesinde isyancılar kadar alkışlayarak kışkırtanlarında etkisi olduğu soncuna varılmış, hatta bu kışkırtıcılardan birinin Yahudi olduğu tespit edilmişti. Nitekim bazıları bu olayın bir Yahudi düzeni olduğunu bile iddia edeceklerdir ${ }^{115}$.

Menemen Olayı, çıkarcıların ve dini hisler sömürücülerinin tertiplediği bir gericilik hareketidir. Mahkeme safhasında olayın geniş kapsamlı olmadığı ortaya çıktığından, yapılan uygulamalarla gözdağı vermekle

Dergisi, "Cumhuriyetin 75. Yıldönümünde Polis Arşiv Belgeleriyle Gerçekler", Özel Sayı, No. 129, (Eylül 1998), s. 53.

12 Hâkimiyet-i Milliye, "Millet Meclisi’nde İdam Kararları Tasdik Edildi", 4 Şubat 1931, Carşamba, No. 3436, s. 1.

3 Şubat 1931 gecesi 27 sanık, Menemen'de idam edilmiştir. Sanıklardan bazılarının Kubilay'ın başının kesildiği yerde asıldığı görülmektedir. Bu arada infazlar gerçekleşirken mahkûmlardan Bozalanlı Hacı İsmail oğlu Hüseyin idam sehpasının önünden kacmıștır. Yapılan araştırmalar sonucunda iki hafta sonra yakalanan mahkûm ertesi gün idam edilmiştir; Hâkimiyet-i Milliye, "Menemen'de Kaçak İdam Mahkûmu Şiddetle Aranıyor", 9 Şubat 1931, Pazartesi, No. 3441, s. 1; Ayın Tarihi, "Menemen İrtica Hadisesi", C. 24, No. 8283, (Subat 1931), s. 6903-6904.

${ }_{14}$ Cemalettin Saraçoğlu, "Menemen İrticai Adı Altındaki Cinayetin Esrar Dolu İç Yüzü”, Tarih Konuşuyor, C. 5, No. 29 (Haziran 1966), s. 2513.

${ }^{15}$ Menemen Olayı sanıklarından birisi olan Hayim oğlu Jozef, (tanık ifadelerine göre) Menemen'de bakkallık yapan ve olay esnasında isyancılara Kubilay'ın kesik basını bayrağa takmak için kullanılan ipi temin eden kişidir. Bkz., Hâkimiyet-i Milliye, "Mahkûmların Vaziyetleri”, 4 Şubat 1931, Çarşamba, No. 3436, s. 4. 
yetinilmiş, idamlar gerçekleștirilmiş ancak Menemen'in boşaltılıp tüm Menemen halkının cezalandırılması yöntemine başvurulmamıştır ${ }^{116}$.

Çıkan olayla ilgili olarak 31 Aralık 1930'da bir ay süre ile ilan edilen sıkıyönetim, 28 Şubat'ta Balıkesir ve Manisa'dan, 8 Mart 1931'de de Menemen'den kaldırılmışıtır ${ }^{117}$.

\section{SONUÇ}

1930 y1lı ekonomik politikada önemli değişikliklerin meydana geldiği bir yıl olmuştur. Cumhuriyetin ilk yıllarında uygulanan liberal ekonomik politika, özellikle "1929 Dünya Ekonomik Buhranı" karşısında beklenilen sonuçları sağlayamamıştı. Gümrük tarifeleri yükselecek diyerek aşırı ithalata gidilmesi, buhran nedeniyle ihracat gelirlerinin beklenmedik düzeye ulaşması ve Türk Lirası'nın hızla değer kaybetmesi, Osmanlı dış borçlarının ilk taksitinin vadesinin gelmesi, özel sektörün elinde yeterince sermaye birikiminin olmamas1, bilgi birikimi ve deneyiminin yetersiz olmas1, yeterli sayıda teknik eleman, vasıflı işçi ve mühendisin bulunmaması, gibi nedenler, toplumda çeşitli tartışmaları beraberinde getirmiştir.

Cumhurbaşkanı Mustafa Kemal Paşa'yı Serbest Cumhuriyet Fırkası'nın kurulmasına yönelten nedenlerin arasında, halk ile iktidar arasındaki iletişimin bütünüyle kopmuş olması gelmektedir. Mustafa Kemal Paşa'ya göre, ülkenin içinde bulunduğu bu sıkıntılardan ancak muhalif bir partinin kurulmasıyla aşılabilecek ve memleketin sorunları Meclis'te muhalefet

${ }^{116} 1930$ yılında TBMM Başkanlığı görevini yürüten Kazım Özalp, Menemen Olayı ile ilgili bilgilerin Ankara'ya ulaşmasından hemen sonra yaşananları anılarında şöyle anlatmaktadır: "Bu haber Ankara'da bir bomba tesiri yaptı. Derhal Köșk'e çağırıldım. Mustafa Kemal Paşa görülmemiş şekilde kızgın, üzgün ve heyecanliydı. İsmet Paşa, Milli Müdafaa Vekili Zekai Bey (Apaydın), Ordu Müfettişi Fahrettin Paşa (Altay) da Köşk'e geldiler. Çok sinirli Mustafa Kemal Paşa hemen söze başladi: 'Bu ne haldir, mürteciler hükümet meydanında ordunun subayın din adına boğazlayabiliyorlar. Binlerce Menemenliden kimse çıkıp mani olmuyor, bilakis tekbirlerle teşvik ediyorlar. Yunan idaresi altındayken bu hainler neredeydiler? Onların namusunu ve dinini kurtaran ordunun bir subayına reva gördükleri bu saldırının cezasın yalnız hain katiller değil, hepsi en ağır şekilde çekmelidir. Bu olay Cumhuriyeti ve bizim bașımızı kesmektir. Bundan bütün Menemen sorumludur. Bu kasaba 'Vilmodit' ilan edilmeye müstahak olmuştur..." Aramızda, bir iki gün beklemeyi, Mustafa Kemal Paşa'nın tepkisinin ne ölçüde değişebileceğini görmeyi uygun gördük. Ancak normal kanuni işleri hemen başlattık. Paşa'dan birkaç gün ses çıkmadı. Bir daha 'Vilmodit' ten bahsetmedi." Fransızca bir sözcük olan "Ville Maudite" cezalandırılmış şehir; "Vilmodit Kasaba" ise, toplumsal olarak işlenen bir suç yüzünden bir kentin cezalandırılması anlamına gelmektedir. Buna göre, "kasabanın bütün halkı șehir dısıına çıkarılmakta, aileler, birer ikişer memleketin başka şehirlerine dağıtılmakta, tam boşaltılmış sehir tümüyle yakılmakta, bugünkü ve yarınki nesillere ibret olmak üzere hükümet meydanına büyük bir siyah taş, sütun olarak dikilmektedir." Bkz., Teoman Özalp, Tanıklık Ediyorum Cumhuriyet ve Atatürk Anıları, 1. B., İstanbul, Epsilon Yayıncılık Hizmetleri Tic. San. Ltd. Sti, 2006, s. 47.

${ }^{117}$ Hâkimiyet-i Milliye, "Menemen Mintıkasında Örfi İdare Martın 8. Gününe Kadar Uzatıldı", 28 Şubat 1931, Cumartesi, No. 3457, s. 1. 
kanadının görüşleriyle tartışılacak, çözümler daha kolay olacaktı. Bu amaçla ikinci çok partili siyasal hayata geçiş çalışmalarına hız verilmiş ve Fethi (Okyar) Bey tarafından kuruluşu gerçekleşen Serbest Cumhuriyet Fırkası ile amaca ulaşılmıştır. Fakat başlayan huzursuzluklar bununla da sona ermemiş ve 1925 Terakkiperver Cumhuriyet Firkası deneyiminde olduğu gibi, bu ikinci denemede de rejim ve devrim karşıtlarının başlattı̆ğ olumsuz gelişmeler, kısa süre içinde bu partinin de kapatılmasında önemli rol oynamıştır. Çünkü toplumda yaygın bir rahatsızlık ve bunalım söz konusu olduğu zaman, yükselen toplumsal muhalefeti güdümlü partilerle yönlendirmek, denetlemek mümkün değildir. Serbest Cumhuriyet Fırkası'nın kapanmasından kısa bir süre sonra meydana gelen Menemen Olayı ise yaşanan bu gelişmeleri doğrulamıştır.

Laik hukuk düzenine ve Cumhuriyete karşı bir ayaklanma niteliğinde gerçekleşen bu olay, tüm yurtta tepkiyle karşılanmıştır. Şehit Kubilay Bey ile Hasan ve Şevki Beylerin cenaze töreni, 25 Aralık 1930'da inkılap ve Cumhuriyetin fedakâr șehitlerine layık bir surette yapılmış ve törene, İzmir'den gelen milletvekilleri, Cumhuriyet Halk Firkası ileri gelenleri, İzmir Belediyesi, Türk Ocağı ve eğitim zümresi namına heyetler, gençler, aydınlar, köylüler ve her sınıf halktan oluşan binlerce kişi katılmıştır.

Menemen'de yaşanan bu acı olay üzerine birçok ilde büyük mitingler düzenlenmiş ve bu mitinglerde gençler "Cumhuriyeti sonsuza dek koruma ve yaşatma sözü" vermişlerdir. Ayrıca bu illerden gelen yüzlerce telgrafta, olay çok sert bir biçimde kınanmıştır.

$\mathrm{Bu}$ yaşanan olumsuz gelişmelerde hayatlarını kaybeden şehitlerin anısına Cumhuriyet gazetesinin girişimiyle Menemen'de bir anıt yaptırılmıştır. Granitten örülmüş büyük bir blok ve birbirine kenetlenmiş üç sütundan oluşan anıtın ön yüzünde "Atatürk'ün gençliğe seslenişi; Inandılar, dövüştüler, öldüler. Bıraktıkları emanetin bekçisiyiz." yazıları ile elinde çelik mızrak taşıyan tunçtan bir genç heykeli vardır. Yine anıtın ön yüzünde Kubilay, Bekçi Hasan ile Şevki Beylerin adları yazılıdır. Halktan toplanan paralarla yaptırılan bu anıt, 24 Aralık 1934'te görkemli bir törenle açılmıştır.

Menemen Olayı'nın etkisi ile 1946 yılına kadar bir daha çok partili siyasal yaşam için herhangi deneme yapılmayacaktır. 


\section{KAYNAKLAR}

Ağaoğlu, Ahmet, Serbest Fırka Hatıraları, 2. B., İstanbul, Baha Matbaas1, 1969.

Akandere, Osman, Milli Şef Dönemi, Çok Partili Hayata Geçişte Rol Oynayan İç ve Dış Nedenler, İstanbul, İz Yayıncılık, 1998.

Akşin, Sina, Ana Çizgileriyle Türkiye’nin Yakın Tarihi 1789-1980, 4. B., Ankara, İmaj Yayıncılık, 2001.

Asım Us, Gördüklerim İstanbul, Duyduklarım, Duygularım, Meşrutiyet ve Cumhuriyet Devirlerine Ait Hatıralar ve Tetkikler, Vakit Matbaası, 1964.

Atatürk'ün Söylev ve Demeçleri, C. II, 5. B., Ankara, Atatürk Araştırma Merkezi Yayınları, 1997.

Atatürk’ün Tamim, Telgraf ve Beyannameleri, C. IV, Ankara, Atatürk Araştırma Merkezi, 1991.

Aybars, Ergün, Atatürk Çağdaşlaşma ve Laik Demokrasi, 1. B., İzmir, İleri Kitabevi Yayınlar1, 1994.

Aybars, Ergün, İstiklal Mahkemeleri 1920-1927, İzmir, Dokuz Eylül Üniversitesi Yayınlar1, 1988.

Ayın Tarihi, "Menemen İrtica Hadisesi”, C. 24, No. 82-83, (Şubat 1931), s. 69036904.

B.C.A, Dos. 2. Büro, Fon. 490. 1. 0. 0, Yer. 527. 654. 211.. 3, (28. 8. 1930).

B.C.A, Dos. 6755, Fon. 30. 10. 0. 0, Yer. 8. 48. 9, (31. 12. 1930).

B.C.A, Dos. 7922, Fon. 30. 10. 0. 0, Yer. 78. 519. 2, (24. 9. 1930).

B.C.A, Dos. 7923, Fon. 30. 10. 0. 0, Yer. 78. 519. 3, (28. 9. 1930).

Çağatay, Neşet, Türkiye'de Gerici Eylemler (1923'den Bu Yana), Ankara, A.Ü. İlahiyat Fak. Yayınları, 1973.

Çavdar, Tevfik, Türkiye'nin Demokrasi Tarihi (1839-1950), 2. B., Ankara, İmge Kitabevi, 1999.

Çetinkaya, Hikmet, Kubilay Olayı ve Tarikat Kampları, 4. B., İstanbul, Çağdaş Yayınları, 1997.

Ertan, Temuçin F ve Diğerleri, Atatürk ilkeleri ve Inkllap Tarihi, 1. B., Ankara, Ankara Üniversitesi Uzaktan Eğitim Yayınları, 2008, s. 196.

Genelkurmay ATASE Başkanlığı Arşivi, "Menemen Olayı Keşif Zabıt Varakası", 23 Aralik 1930, D. 1, F. 1-1.

Goloğlu, Mahmut, Devrimler ve Tepkileri (1924-1930), Ankara, Başnur Matbaas1, 1972. 
Goloğlu, Mahmut, Türkiye Cumhuriyeti, Ankara, Başnur Matbaası, 1971.

Hâkimiyet-i Milliye, "Yeni Frrka", 10 Ağustos 1930, Pazar, No. 3260, s. 1, 3.

Hâkimiyet-i Milliye, “İsmet Paşa Yeni Fırka Hakkında Ne Düşünüyorlar?”, 11 Ağustos 1930, Pazartesi, No. 3261, s. 1-2.

Hâkimiyet-i Milliye, “Gazi Hazretleri Fethi Bey’e Cevap Verdiler.”,12 Ağustos 1930, Sal1, No. 3262, s. 1.

Hâkimiyet-i Milliye, "Serbest Cumhuriyet Fırkası Teşekkül Etti.", 13 Ağustos 1930, Çarşamba, No. 3263, s. 1.

Hâkimiyet-i Milliye, "Yeni Fırka Reisinin Yeni Beyanatı, Fethi Bey Teşkilatla Meşgul Oluyor", 15 Ağustos 1930, Cuma, No. 3265, s. 1-4.

Hâkimiyet-i Milliye, "Serbest Fırka Faaliyete Başladı.”, 17 Ağustos 1930, Pazar, No. 3267, s. 1 .

Hâkimiyet-i Milliye, "Sivas İstasyonu Dün Büyük Merasimle Açıldı ve Muhterem Başvekilimiz Atideki Mühim Nutuklarını İrat Ettiler”, 31 Ağustos 1930, Pazar, No. 3281, s. 1.

Hâkimiyet-i Milliye, “Karşı Fırkanın Reisi İzmir’e Gitti.”, 4 Eylül 1930, Perşembe, No. 3285, s. 3.

Hâkimiyet-i Milliye, "SCF Lideri İzmir'e Gitti. Nutkunu Cumartesi Günü Söyleyecek", 5 Eylül 1930, Cuma, No. 3286, s. 5.

Hâkimiyet-i Milliye, “İzmir'de Şayan-1 Teessüf ve Teessür Hadiseler”, 6 Eylül 1930, Cumartesi, No. 3287, s. 1.

Hâkimiyet-i Milliye, “Fethi Bey İzmir'e Gittiği Gün Neler Oldu?”, 6 Eylül 1930, Cumartesi, No. 3287, s. 2.

Hâkimiyet-i Milliye, "Fethi Bey Nutkunu Söyledi”, 8 Eylül 1930, Pazartesi, No. 3289, s. 3.

Hâkimiyet-i Milliye, "Fırkalar Karşısında Gazi”, 8 Eylül 1930, Pazartesi, No. 3289, s. 1.

Hâkimiyet-i Milliye, "Reis-i Cumhur Hazretleri ve Yeni Fırka", 9 Eylül 1930, Salı, No. 3290, s. 1.

Hâkimiyet-i Milliye, "Reis-i Cumhur Hazretleri Milleti Tenvir Ediyor", 10 Eylül 1930, Çarşamba, No. 3291, s. 1.

Hâkimiyet-i Milliye, "Fethi Bey İstanbul'da”, 14 Eylül 1930, Pazar, No. 3295, s. 1.

Hâkimiyet-i Milliye, “Adliye Vekili’nin İstifası”, 24 Eylül 1930, Çarşamba, No. 3305, s. 1. 
Hâkimiyet-i Milliye, "Serbest Fırka'nın Feshi Hakkında”, 19 Kasım 1930, Çarşamba, No. 3359, s. 1.

Hâkimiyet-i Milliye,"Menemen Hadisesi”, 25 Kanun-u Evvel (Aralık) 1930, Perşembe, No.3395, s. 1.

Hâkimiyet-i Milliye, "Menemen'de Tahkikat Ehmiyetle Devam Ediyor”, 27 Kanun-u Evvel (Aralik) 1930, Cumartesi, No.3397, s. 1-3.

Hâkimiyet-i Milliye, “Menemen'de Tahkik Heyeti Yeni Tevkifât Yaptı. Yakalanan Hacı ve Hocalar”, 28 Kanun-u Evvel (Aralık) 1930, Pazar, No. 3398, s. 1-3.

Hâkimiyet-i Milliye, “Kazım ve Fevzi Paşalar İstanbul'a Gitti. Paşalar Doğruca Dolmabahçe'ye Gittiler.”, 28 Kanun-u Evvel (Aralık) 1930, Pazar, No. 3398, s. 1 .

Hâkimiyet-i Milliye, “Gazi Hz. Kublay Bey’in Şehâdeti Dolayısıyla Cumhuriyet Ordusunu Taziyet Etti.”, 29 Kanun-u Evvel (Aralı) 1930, Pazartesi, No. 3399, S. 1.

Hâkimiyet-i Milliye, "Müşür Paşa Ordunun Layezal Rabıtasını Reis-i Cumhur Hazretlerine Bizzat Arzetti.”, 29 Kanun-u Evvel (Aralık) 1930, Pazartesi, No. 3399, s. 1.

Hâkimiyet-i Milliye, “Korkunç Bir Sahne, İrtica Çetesi Kubilay’ın Başını Nasıl Kesti”, 29 Kanun-u Evvel (Aralık) 1930, Pazartesi, No. 3399, s. 1.

Hâkimiyet-i Milliye, "Dâhiliye Vekilinin Nutku.”, 30 Kanun-u Evvel (Aralık) 1930, Sal1, No. 3400, s. 3.

Hâkimiyet-i Milliye, "İrtica Hadisesi Müretteptir ve Şumullüdür. Frrka Grubunda Hadise Üzerinde Heyecanlı Müzakerat Oldu”, 31 Kanun-u Evvel (Aralık) 1930, Çarşamba, No. 3401, s. 1.

Hâkimiyet-i Milliye, "Divanı Harp Teşekkül Etti ve Örfi İdare Amirliği'ne Fahrettin Paşa Tayin Edildi”, 2 Kanun-u Sani (Ocak) 1931, Cuma, No. 3403, s. 1,4.

Hâkimiyet-i Milliye, "Başvekil Paşa İrtica Hadisesine Dair Sual Takririne Cevap Verdi”, 3 Kanun-u Sani (Ocak) 1931, Cumartesi, No. 3404, s. 1,3.

Hâkimiyet-i Milliye, "Mazhar Müfit Bey’in Beyanatı", 3 Kanun-u Sani (Ocak) 1931, Cumartesi, No. 3404, s. 3.

Hâkimiyet-i Milliye, "Menemen'de Divanı Harp Bugün İşe Başladı", 16 Kanun-u Sani (Ocak) 1931, Cuma, No. 3417, s. 1, 3.

Hâkimiyet-i Milliye, "Divanı Harp İlk Kararını Verdi. Suçsuz Olan Üç Kişi Beraat Etti.”, 29 Kanun-u Sani (Ocak) 1931, Perşembe, No. 3430, s. 1.

Hâkimiyet-i Milliye, "Divanı Harpte Suçsuz Olanlar Dün Beraat Etti. Beraat Edenler", 30 Kanun-u Sani (Ocak) 1931, Cuma, No. 3431, s. 1-2. 
Hâkimiyet-i Milliye, "İrtica Maznunlarından Biri Öldü”, 30 Kanun-u Sani (Ocak) 1931, Cuma, No. 3431, s. 2.

Hâkimiyet-i Milliye, "Divanı Harbin Kararı-Karar Millet Meclisi'ne Bildirildi", 2 Şubat 1931, Pazartesi, No. 3434, s. 1,4.

Hâkimiyet-i Milliye, "Divanı Harbin Kararı-İdama Mahkûm Edilenler", 2 Şubat 1931, Pazartesi, No. 3434, s. 4.

Hâkimiyet-i Milliye, "Divanı Harbin Kararı-Sinleri İcabı İdama Bedel 24 Sene Hapise Mahkûm Edilenler", 2 Şubat 1931, Pazartesi, No. 3434, s. 4.

Hâkimiyet-i Milliye, "Divanı Harbin Kararı-Derecatı Muhtelifede Hapis Ağır Hapis Cezalarına Mahkûm Edilenler", 2 Şubat 1931, Pazartesi, No. 3434, s. 4.

Hâkimiyet-i Milliye, "Divanı Harbin Kararı-Üçer Sene Hapse Mahkûm EdilenlerBirer Sene Hapse Mahkûm Edilenler", 2 Şubat 1931, Pazartesi, No. 3434, s. 4.

Hâkimiyet-i Milliye, "Millet Meclisi'nde İdam Kararları Tasdik Edildi", 4 Şubat 1931, Çarşamba, No. 3436, s. 1.

Hâkimiyet-i Milliye, "Menemen'de Kaçak İdam Mahkûmu Şiddetle Aranıyor", 9 Şubat 1931, Pazartesi, No. 3441, s. 1.

Hâkimiyet-i Milliye, "Mahkûmların Vaziyetleri”, 4 Şubat 1931, Çarşamba, No. 3436, s. 4.

Hâkimiyet-i Milliye, "Menemen Mıntıkasında Örfi İdare Martın 8. Gününe Kadar Uzatıldı", 28 Şubat 1931, Cumartesi, No. 3457, s. 1.

Karpat, Kemal H., Türk Demokrasi Tarihi, 2. B., İstanbul, Afa Yayınları, 1996.

Kırçak,Çağlar, Meşrutiyetten Günümüze Gericilik, 2. B., Ankara, İmge Kitabevi, 1994.

Kinross, Lord, Atatürk, Bir Milletin Yeniden Doğuşu, Çev. Necdet Sander, 10. B., İstanbul, Altın Kitaplar, 1984.

Okyar, Fethi, Üç Devirde Bir Adam, Yay. Haz., Cemal Kutay, İstanbul, AdamTercüman Yayınları, 1980.

İnönü, İsmet, Hatıralar, 2. Kitap, Ankara, Yenigün Haber Ajansı Basın ve Yayıncilık A.Ş., 1999.

Özek, Çetin, Gerici Akımlar ve Nurculuğun İç Yüzü, İstanbul, Ekin Basımevi, 1964.

Özalp, Teoman, Tanıklı Ediyorum Cumhuriyet ve Atatürk Anıları, 1. B., İstanbul, Epsilon Yayıncılık Hizmetleri Tic. San. Ltd. Şti, 2006.

Saraçoğlu, Cemalettin, "Menemen İrticai Adı Altındaki Cinayetin Esrar Dolu İç Yüzü”, Tarih Konuşuyor, C. 5, No. 29, (Haziran 1966), s. 2429-2430. 
Saraçoğlu, Cemalettin, "Menemen İrticai Adı Altındaki Cinayetin Esrar Dolu İç Yüzü”, Tarih Konuşuyor, C. 5, No. 29 (Haziran 1966), s. 2433.

Soyak, Hasan Riza, Atatürk'ten Hatıralar, C. II, Ankara, Yapı Kredi Bankası Yayınları 1973.

Uran, Hilmi, Hatıralarım, Ankara, Ayyıldız Matbaası, 1959.

Tanfer, Vehbi, "İrtica Olayları Karşısında Atatürk", Atatürk Araştırma Merkezi Dergisi, C. VI, No. 17, (Mart 1990) s. 318.

Tekeli, İlhan; Selim İlkin, 1929 Dünya Buhraninda Türkiye'nin İktisadi Politika Arayışları, Ankara, Orta Doğu Teknik Üniversitesi, 1977.

Teziş, Erdoğan, Atatürk Döneminin Ekonomik ve Toplumsal Sorunlarl, İstanbul, İktisadi ve Ticari İlimler Akademisi Mezunlar Derneği Yay., 1977.

Tunaya, Tarık Zafer, Türkiye'de Siyasi Partiler, 2. B., İstanbul, Hürriyet Vakfı Yay., 1986.

Tunçay, Mete, Türkiye Cumhuriyeti'nde Tek Parti Yönetiminin Kurulması (19231931), Ankara, Yurt Yayınları, 1981.

Turan, Şerafettin, Türk Devrim Tarihi, Ulusal Direnişten Türkiye Cumhuriyeti'ne, 1. B., 2. Kitap, Ankara, Bilgi Yayınevi, 1992.

Turan, Şerafettin, Türk Devrim Tarihi, Yeni Türkiye'nin Oluşumu 1923-1938, 3. Kitap, Ankara, Bilgi Yayınevi, 1995.

Türk İnkılap Tarihi Enstitüsü Arşivi, "Şehit Asteğmen Mustafa Fehmi Kubilay" Fotoğraf Kutusu (FK) 51, Gömlek (G) 55, Belge (B) 55001.

Türk İnkılap Tarihi Enstitüsü Arşivi, "Şehit Asteğmen Mustafa Fehmi Kubilay’ın Şapkası" Müze Evanter No: 1117.

Yetkin, Çetin, Serbest Cumhuriyet Fırkası Olayl, İstanbul, Karacan Yayınları, 1982. 
Belge No:13212-5/3

suret

$$
\frac{\text { Uenemen }}{23-I 2-930}
$$

43 . Alay . I.T.3.BL.

Takim zablti

Intiyat zablt vekil1

toplay of. bin Euseyin

Imix

322

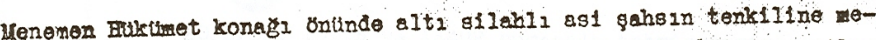

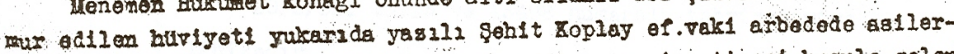
den her bengl birisl tarafinden ondaht edslen werm neticesi husulo gelon

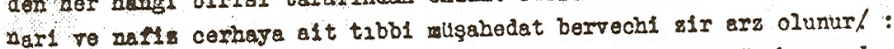

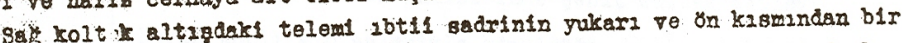
axkl bos para kutrunda girls deligl gozukmaktedir.delik çerçiresinde ba-

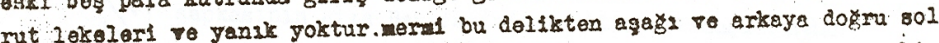

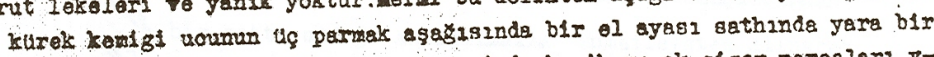

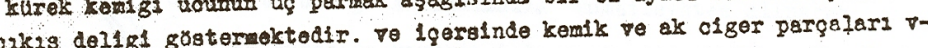

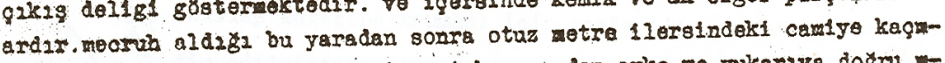

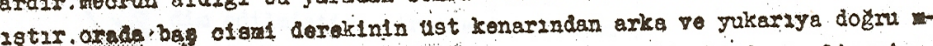

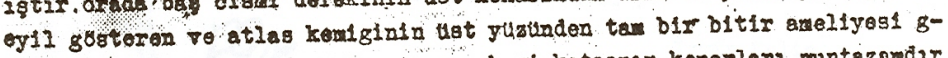

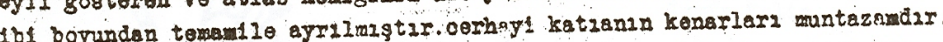

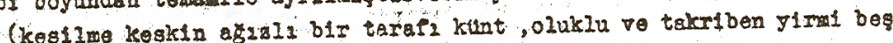

(kesline loskin as

Notioe : bagl kesis, olum lik yaralamanin verdigl ahlis ve haricl kan-

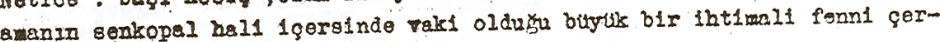
givosL lgersindeds.

43. Alay Bas Hok. Yrb

( E.Sust)

$336-63$

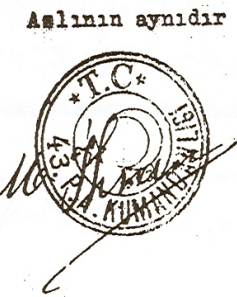

Menomen Hukitmet Mek.

43 . Al'y . Hek.

I.MID.

(Necat1)

$928-7$

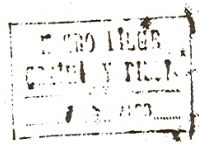

- 8 TEMMUZ 298

Emniyet Genel Müdürlüğü Polis Dergisi, “Cumhuriyetin 75. Yıldönümünde Polis Arşiv Belgeleriyle Gerçekler”, Özel Sayı, No. 129, (Eylül 1998), s. 67. 


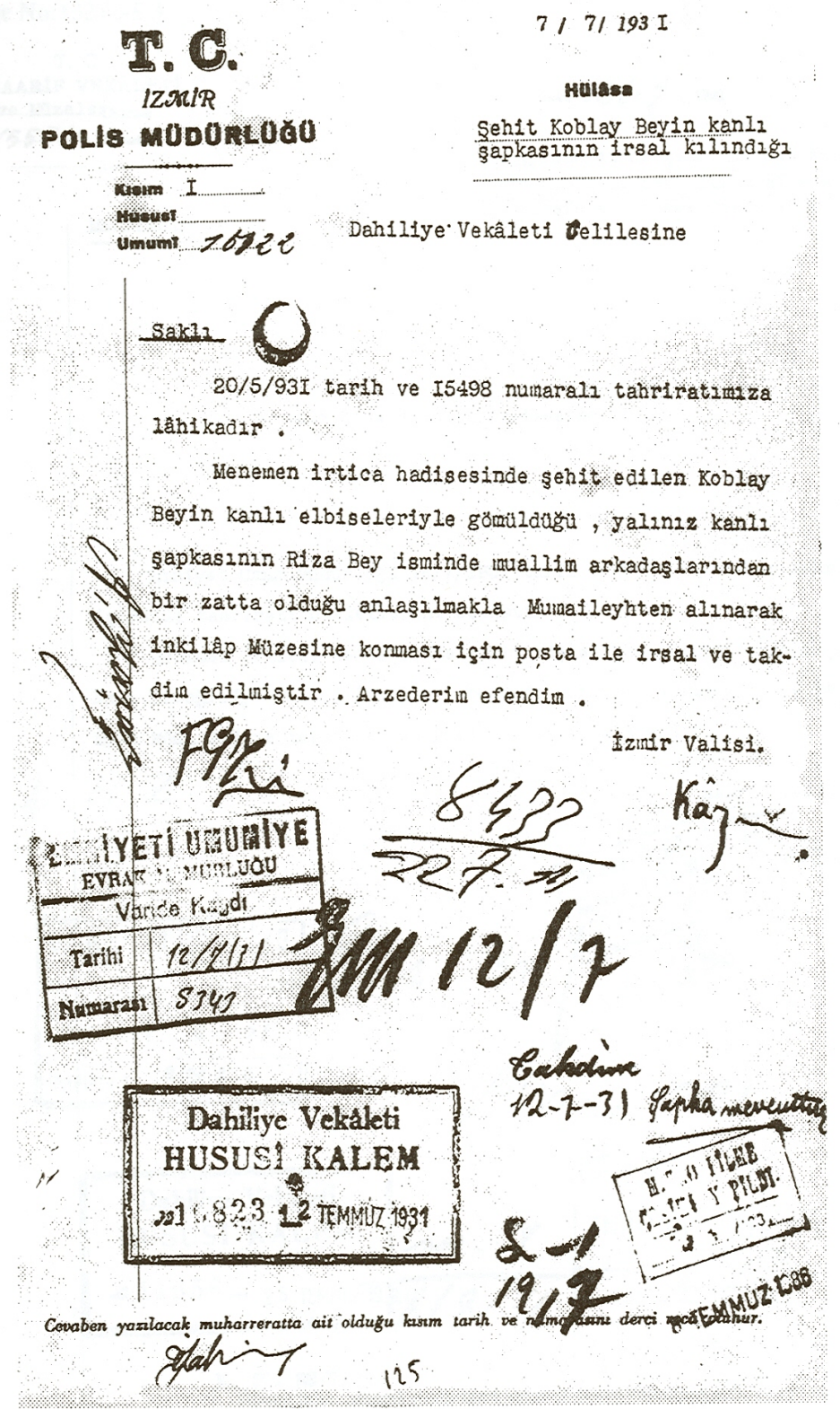

Emniyet Genel Müdürlüğü Polis Dergisi, “Cumhuriyetin 75. Yıldönümünde Polis Arşiv Belgeleriyle Gerçekler”, Özel Sayı, No. 129, (Eylül 1998), s. 74. 
Belge No:13212-5/3

T. C.

MAARTF VEKALETI

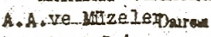

85.5 .54 . Hurmi

Un

Mahremdir

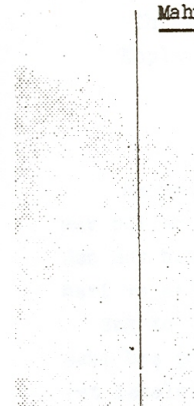

Mniyat Umum Madurlusti $18 / 7 / 1931$ tarih ve 6446 sayil ve mahrom fsaretil tahrirati devletlerine cevaptir :

Menemen Irtica hadisesinde sehlt edilen Kublay Beyin Kanli sap-


Laze wadurlukgne teslim edildigini arz eylerim Efendin.

A

H. Z.

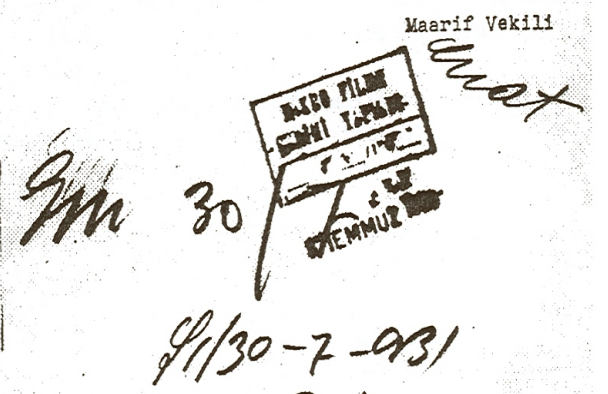

Dahiliye Vekaleti $B \cdot 1$ HUSUSI KALFM

$-11656-26$. TEMMUZZ

4. Su. $20 / 7 / 931$

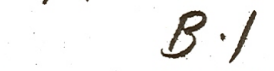

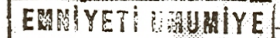

EVR : STILOQU

Tarihi $-3 a-z-21$

Numaras 5866

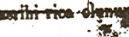

Emniyet Genel Müdürlüğ̈̈ Polis Dergisi, “Cumhuriyetin 75. Y1ldönümünde Polis Arşiv Belgeleriyle Gerçekler”, Özel Sayı, No. 129, (Eylül 1998), s. 75. 


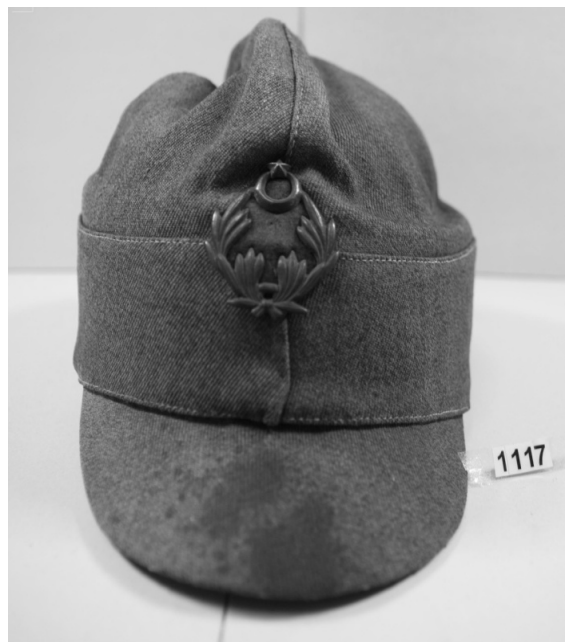

Şehit Asteğmen Mustafa Fehmi Kubilay'ın Şapkası, Türk Inkılap Tarihi Enstitüsü Arşivi, Müze Evanter No: 1177.

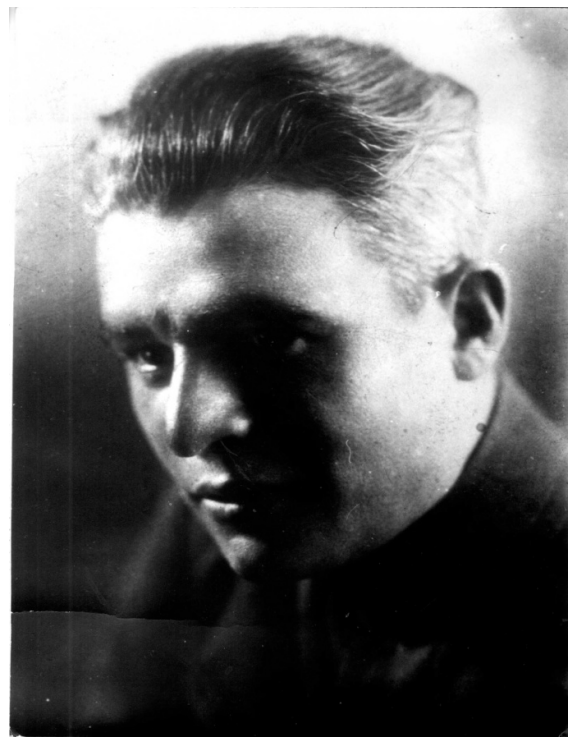

Şehit Asteğmen Mustafa Fehmi Kubilay, Türk Inkılap Tarihi Enstitüsü Arşivi, Fotoğraf Kutusu (FK) 51, Gömlek (G) 55, Belge (B) 55001. 


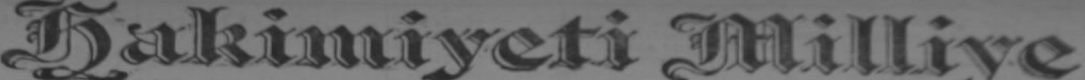

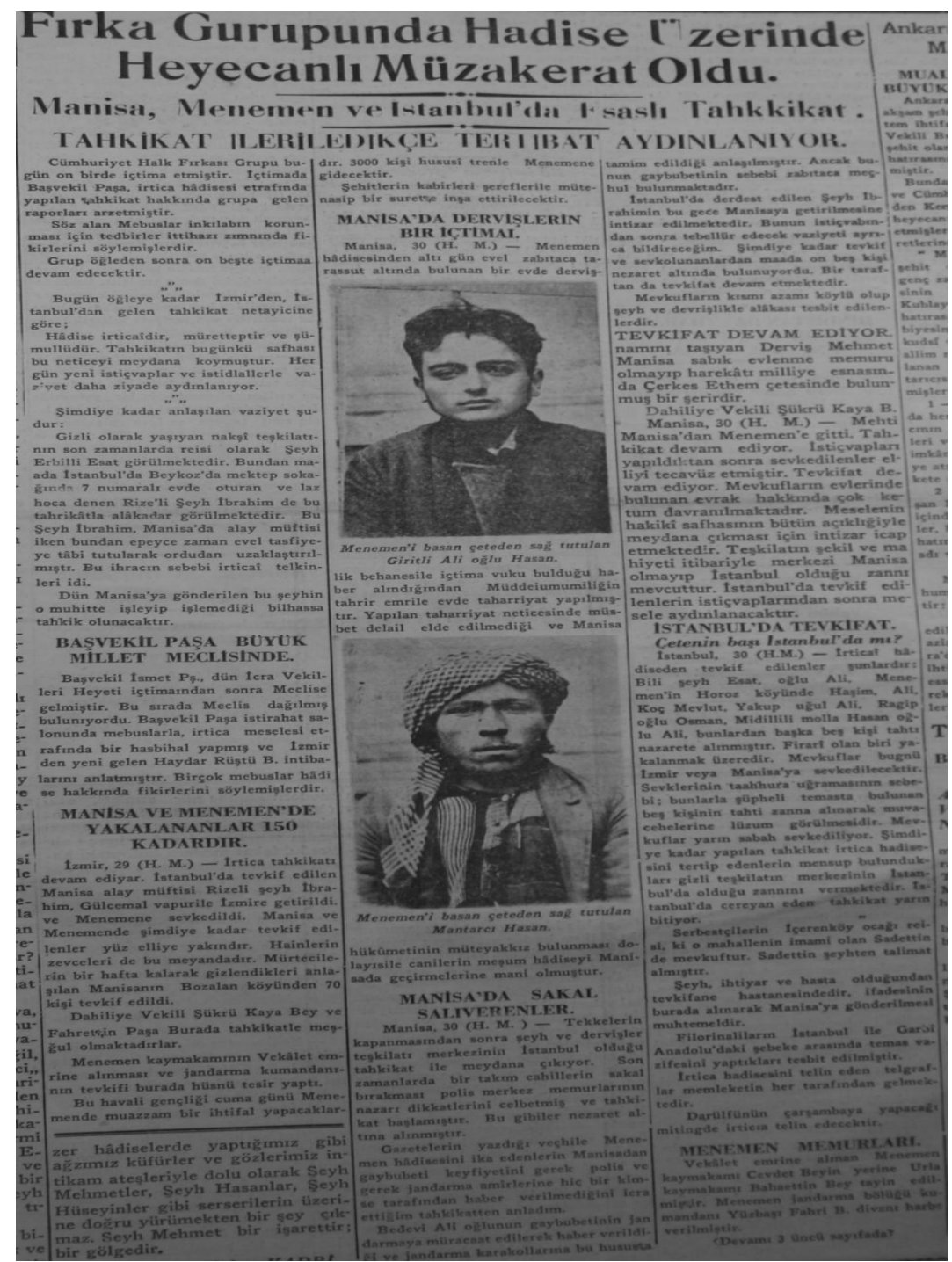

Hâkimiyet-i Milliye, "İrtica Hadisesi Müretteptir ve Şumullüdür. Fırka Grubunda Hadise Üzerinde Heyecanlı Müzakerat Oldu”, 31 Kanun-u Evvel (Aralık) 1930, Çarşamba, No. 3401, s. 1. 

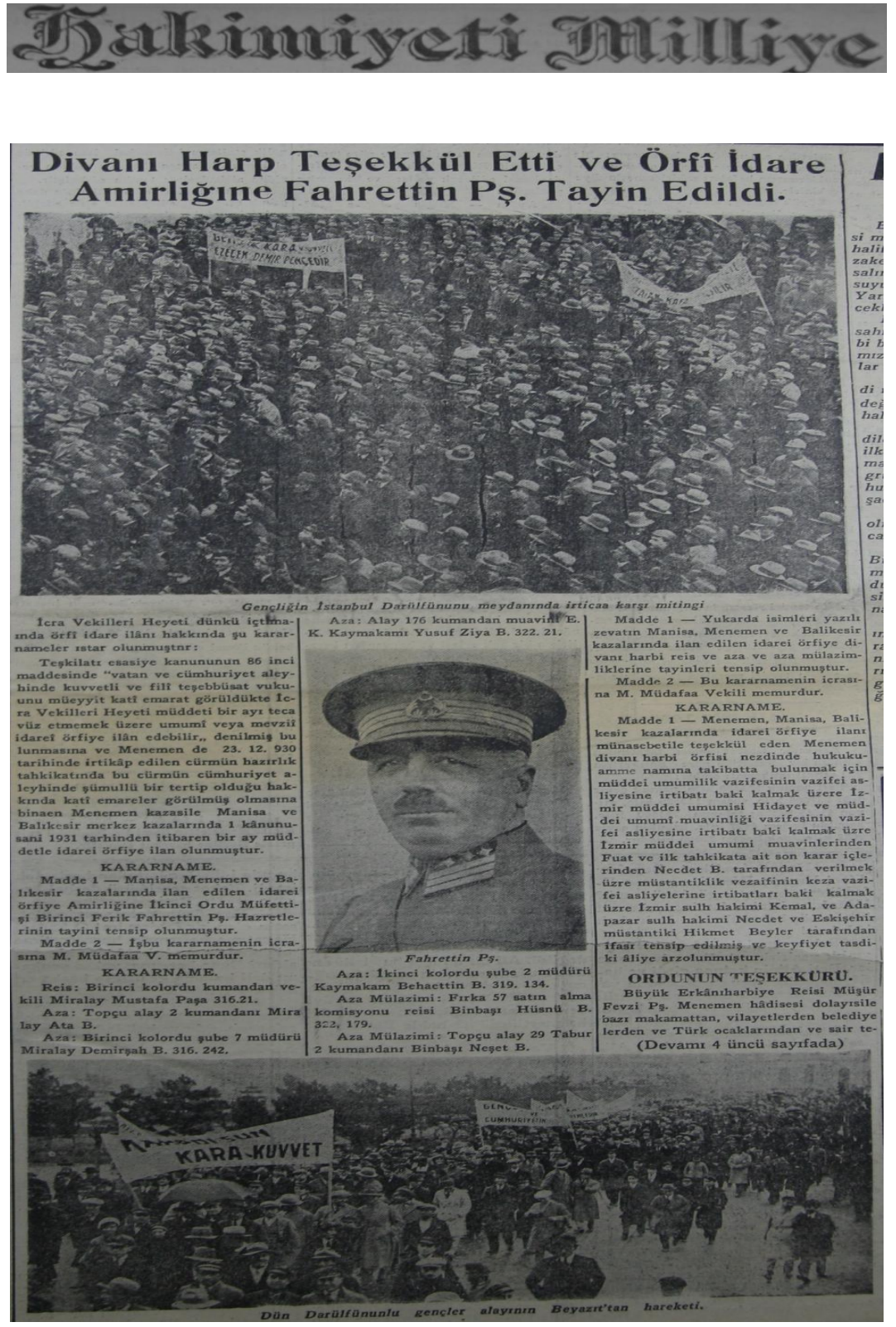

Hâkimiyet-i Milliye, "Divanı Harp Teşekkül Etti ve Örfi İdare Amirliği'ne Fahrettin Paşa Tayin Edildi”, 2 Kanun-u Sani (Ocak) 1931, Cuma, No. 3403, s. 1. 


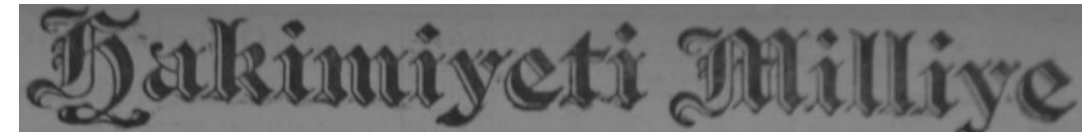

\section{Divanı Harbin Kararı. \\ Karar Millet Meclisine Bildirildi. \\ KIMLER IYDAMA MAHKOM OLDU?}

Divanr harbin iydam hakkındaki kara runi muhtevi tezkere meclisi Adliye en cümenine havale edilmiş ve bugün en cümen tarafından müzakeresine başlan mıştır. Bu suretle kararın yarınki celse de müzakeresi mukarrerdir.

Divanr harbin kararr Milli Müdafaa vekilliğinin şu teskeresiyle meclise bil dirilmiştir:

1 - Menemen hâdisei isyaniyesini tertip, ihzar ve teşvik ederek bu suçu işlemiye azmettirerek Türkiye Cümhuriyeti teşkilatı esasiye kanunınu tağyire cebren teşebbuis etmekle maznun olan eşhastan isimleri merbut listede yaztl otuz yedi şahsın aledderecat müsellahan harekete geçerçk ve mehdilik :lan ede. rek Menemen hâdisesini doğrudan doğruya beraber işlemek ve azmettirmek suretlerile teşkilatı esasiye kanununu tağyire teşebblis eyledikleri sabit oldu(Devamı dördüncü sahıfada)

\section{Divanı Harbin Kararı}

(Baştaraft 1 inci sayıfada)

ğundan hareketlerine tevafuk eden Türk ceza kanununun 64 üncü maddesinin birinci ve ikinci fıkraları delaletiyle 146 met maddesine tevfikan iydamlarma ve ancak içlerinden altısımm yaşları dolayısile mezkûr kanunun 55 ve 56 mer maddeleri mucibince haklarındaki iydam 15 ve 24 sene ağır hapis cezasına tahviline:

$2-41$ sahsın muttali oldukları is. yan hareketini sui niyetle hükûmete ih bar etmemek ve dini alet ittihaz ile hakı devletin emniyetini ihlal edebilecek harekete teşvik eylemek ve tekkelerin sed dine dair olan kanunun meriyetinden sonra ayini tarikat ifa etmek suçlarmı ișlemiș olmalarmadan dolayı tiirk ceza kanununun 151 inci maddesinin birinci fıkrasi ve 163 üncü maddesinin birinci frkrast ve 677 numarals kanun hükümlerine tevfikan derecatr muhtelife de hapis ve ağır hapis cezalarile mücazatlarma :

$3-V e 27$ șahsın beraetlerine dair Menemen Divant Harbi Orfisinden sadir olan hükümleri havi 25 kânunusani 1931 tarih ve 4 numaralt karar ve teferruats leffen arz ve takdim kılınmıștrr.

Hâkimiyet-i Milliye, "Divanı Harbin Kararı-Karar Millet Meclisi’ne Bildirildi”, 2 Şubat 1931, Pazartesi, No. 3434, s. 1,4. 


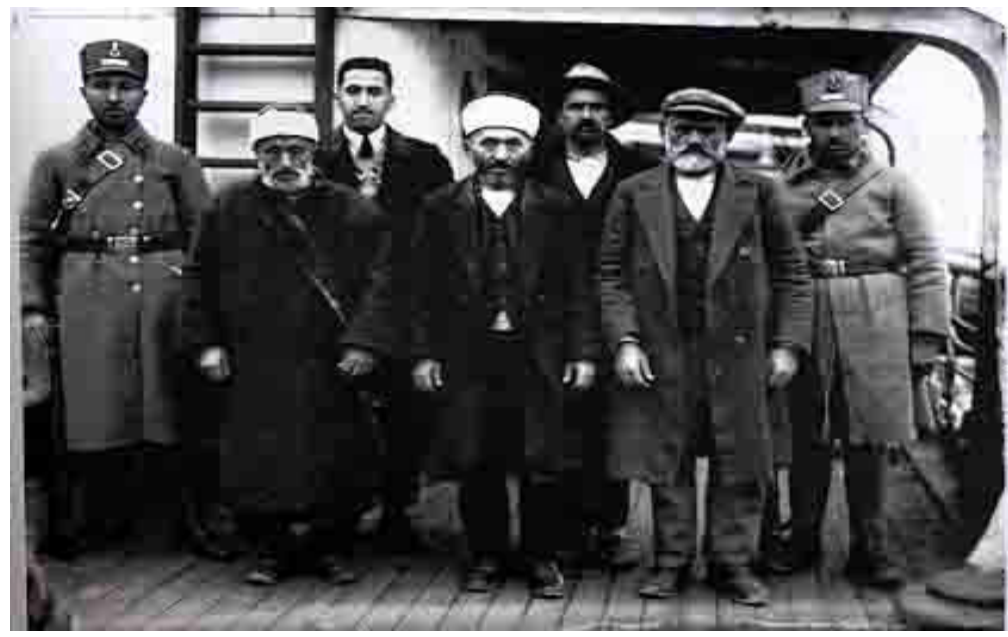

3 Şubat 1931'de infazları gerçekleşen asilerden bazıları. "Laz İbrahim Hoca, Çingene Ali, Cemal Hoca, Menemenli Ramiz, Menemenli Yahya oğlu Hüseyin”

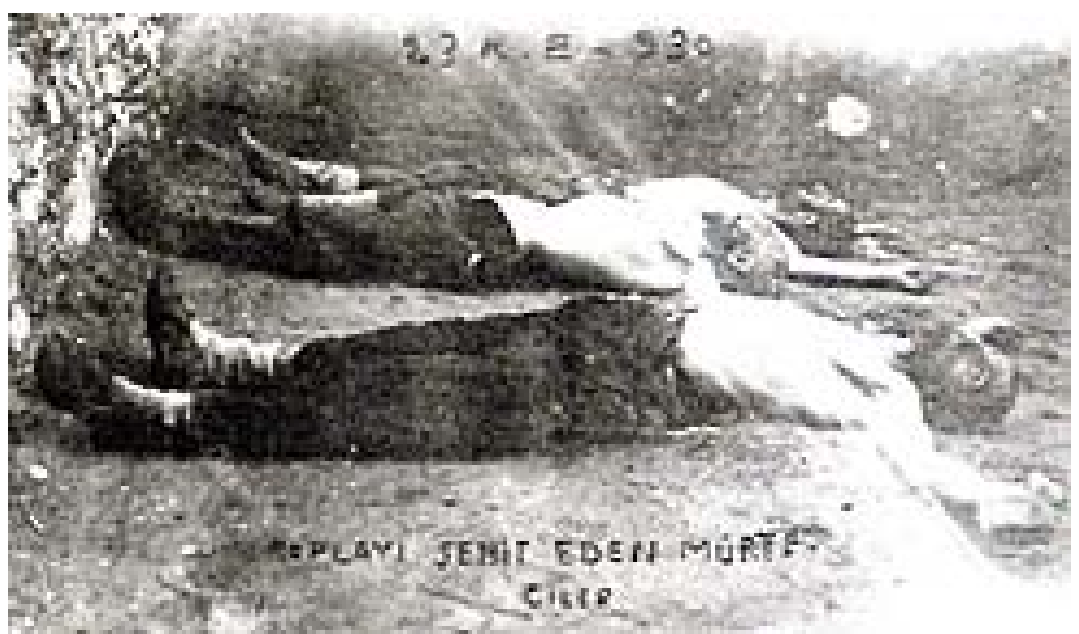

23 Aralık 1930'da güvenlik güçleri ile girdikleri çatışmada ölen asiler 